\title{
Role of Selfie in Creating Identity in Social Media in Kurdistan Region
}

\author{
Ismael Osman Abdulrahman \\ Master in Social and Communication SciencesMedia and Culture \\ University of Sulaimani \\ Iraq \\ esmailhauramani@gmail.comEmail:
}

\begin{abstract}
Recent developments in communication technology have brought new changes in the daily life of the individuals in the society, particularly after the development of smart phones and the release of a wide range of applications or "apps." Sharing self-portrait type images (Selfies) have become a daily culture for many social media users, particularly young people who share their photos through smart phones and different applications, including Snapchat. They want to create a new identity for themselvesthat is located within the online context. Taking and sharing the photos tell the followers: "look at me." The term "selfie" was first added tothe Oxford English Dictionary in November 2013 and the phenomenon has now begun to be studied in the academic world. This research will investigate the behavior of 20 male and female users of social media, aged between 20 and 30 years old,and analyzehow they share their photos on Snapchat. The theory of Tafman ${ }^{1}$, which argues that there are similarities between theater and the daily behavior of individuals, and the theory of Symbolic of Sorsor ${ }^{2}$ and Pers ${ }^{3}$, who are $\mathrm{Dal}^{4}$ and Madlul ${ }^{5}$, were used in the research. The result of the research reveals that youths want to create an online identity for themselves through the sharing of symbolic photos ${ }^{1}$, which allows them to perform their desires, wishes, and social media attitudes.
\end{abstract}



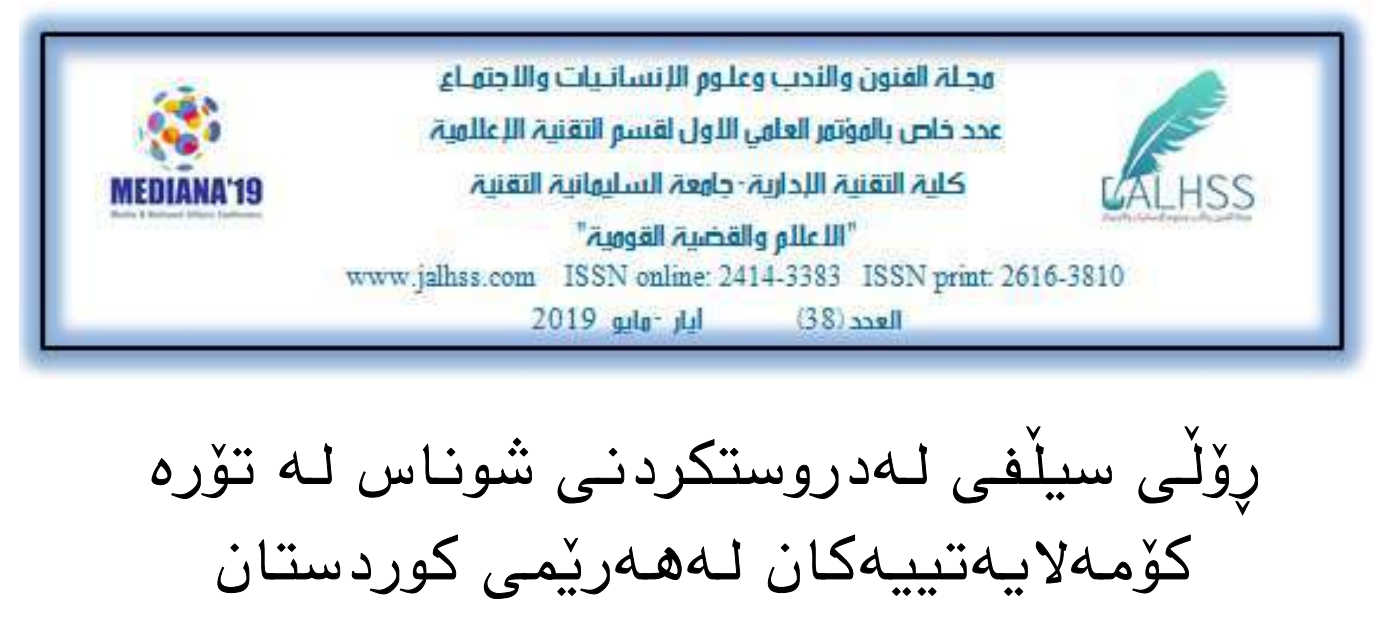

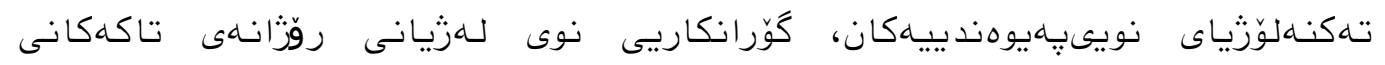

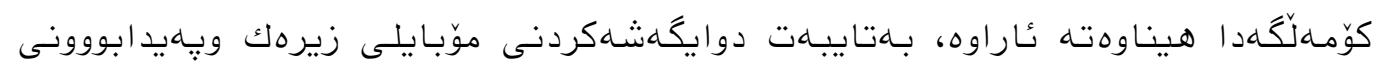

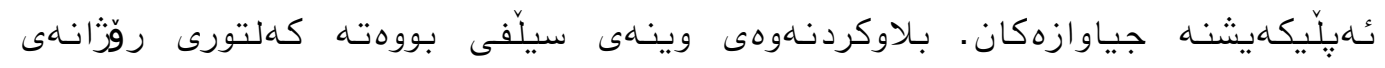

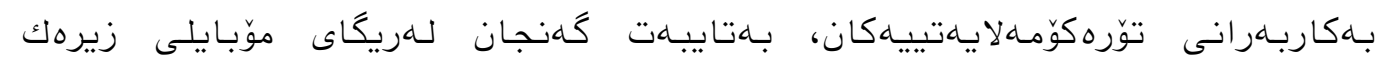

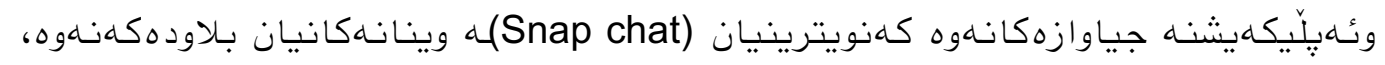

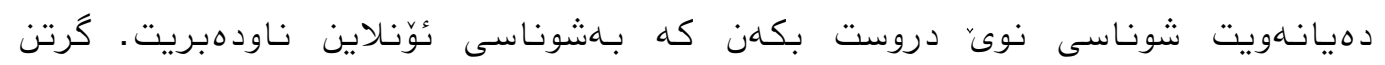

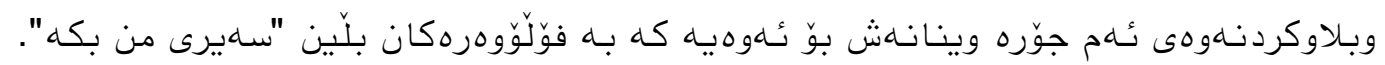

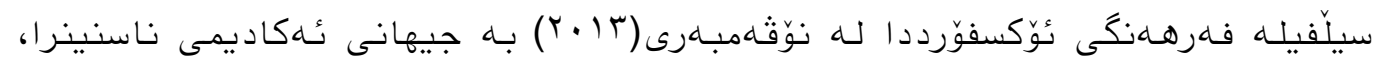

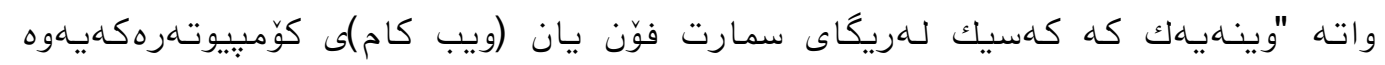

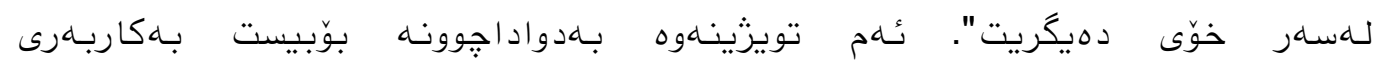

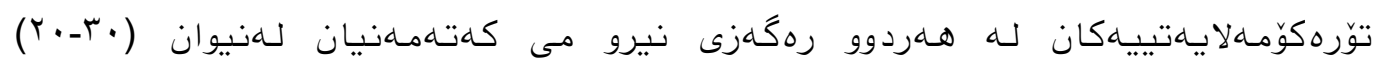

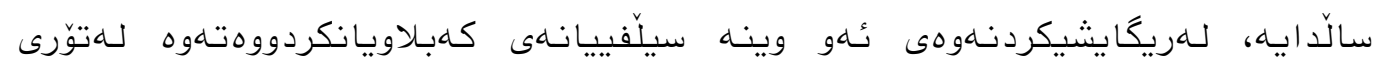

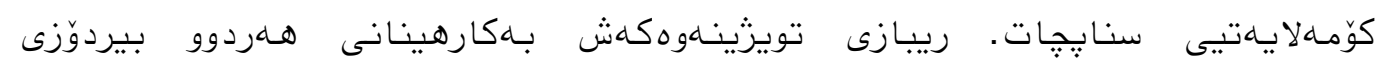

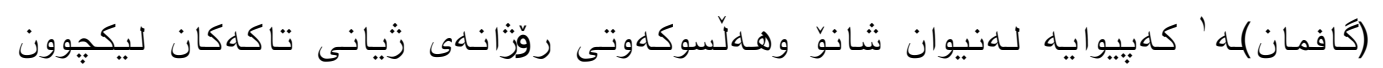

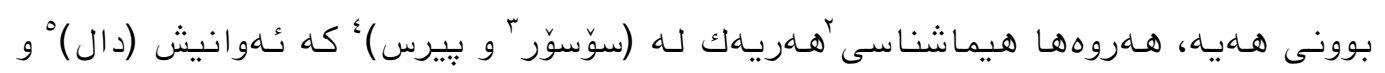

${ }^{1}$ Dramaturgical Analysis

2 Symbolic

${ }^{3}$ Fredinand de sosuier (1987-1913)

${ }^{4}$ Charles sandres perice (1839-1914)

${ }^{5}$ signifier 


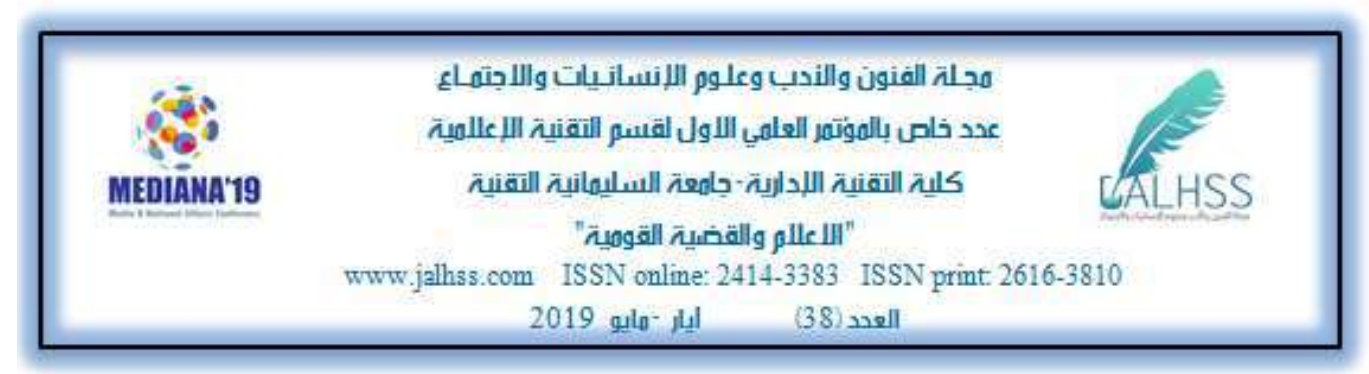

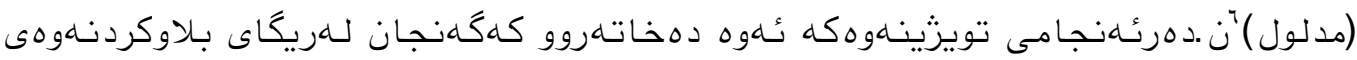

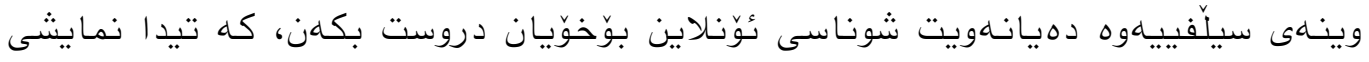

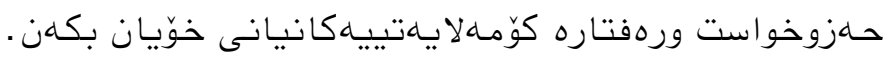

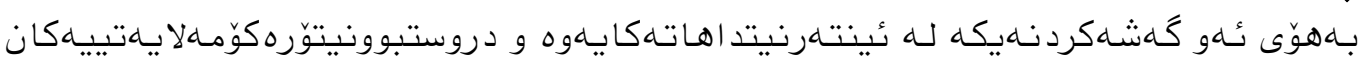

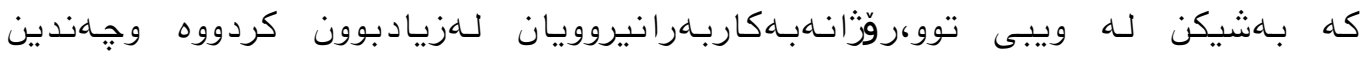

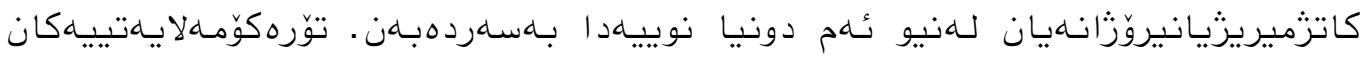

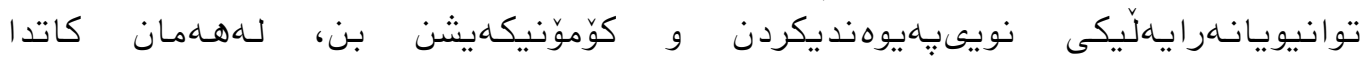

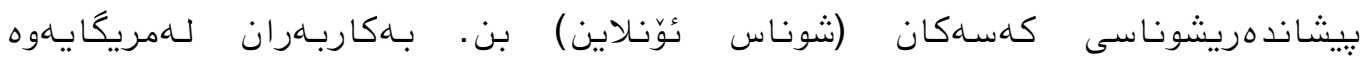

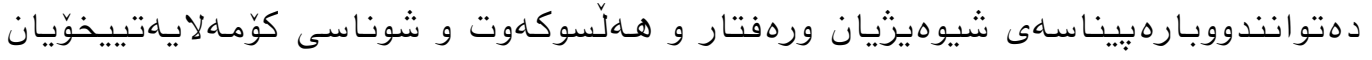

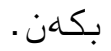

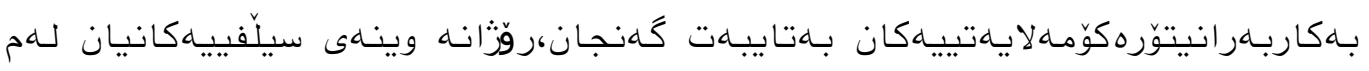

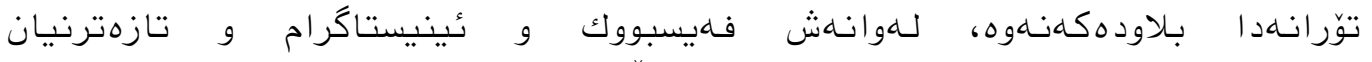

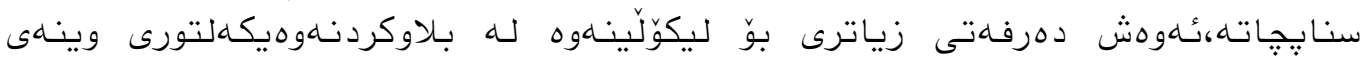

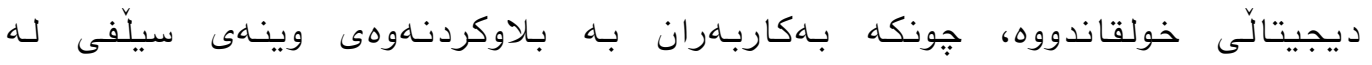

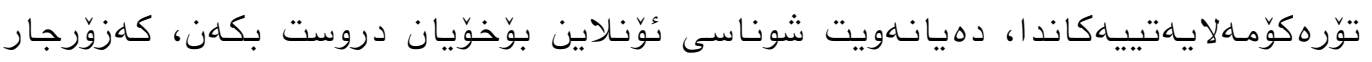

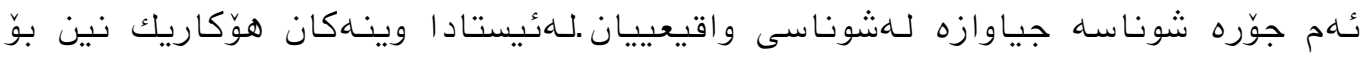

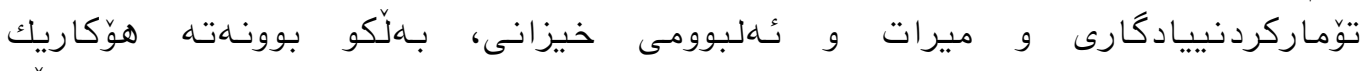

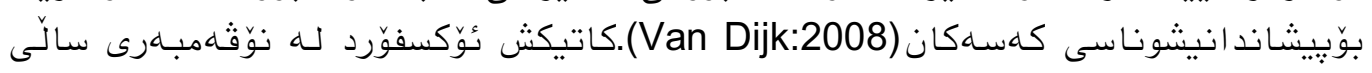

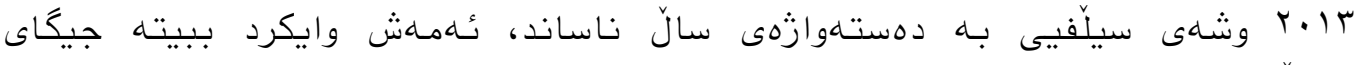

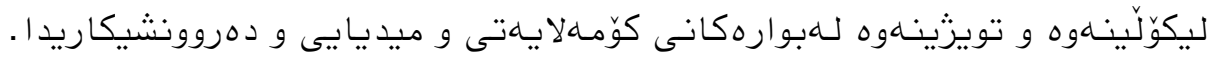

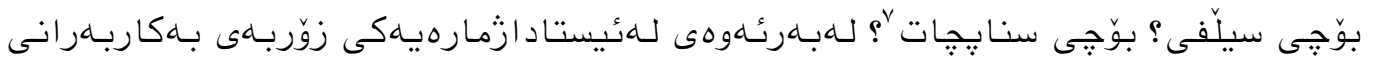

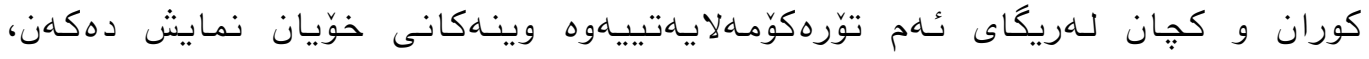

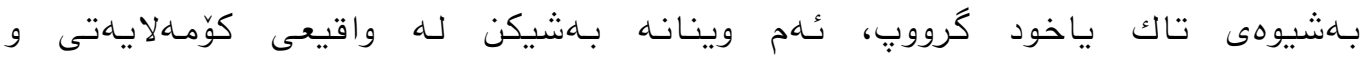

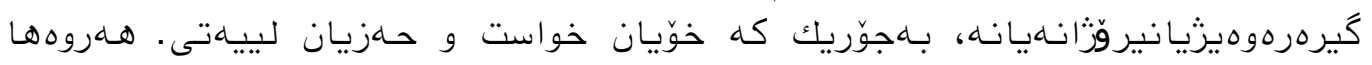

\section{6 signifified}

${ }^{7}$ Snap chat, Robert Cornelius Murphy

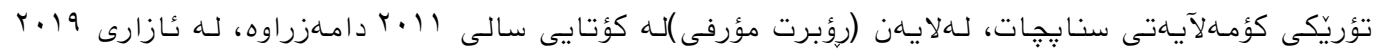

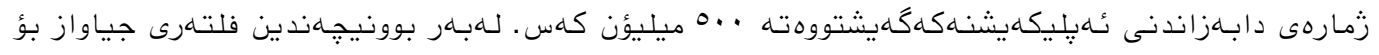

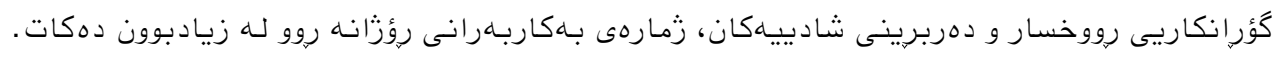


ising
هجلِ الفنون والندب وعلوم اللإنسانيات واللاجتمـاع

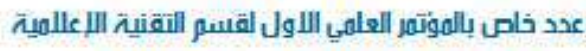

كلية التقنية اللدازية -جاهعت السليهانية التهنيت

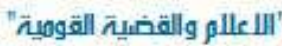

www.jalhss.com ISSN online: 2414-3383 ISSN print $2616-3810$

2019 glo الع

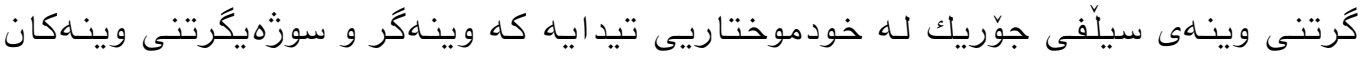
خودى كهسهكه خوّيهتى، دهيهويت بـهوانترين شيوه خوّى نمايش بكات، فوّلوَوهرهكان

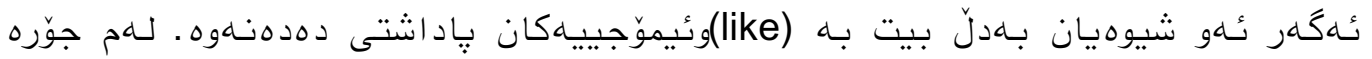

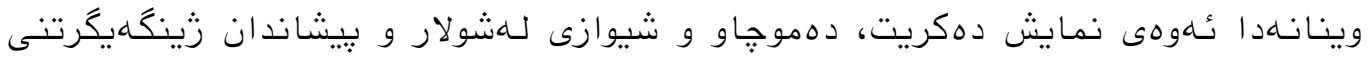

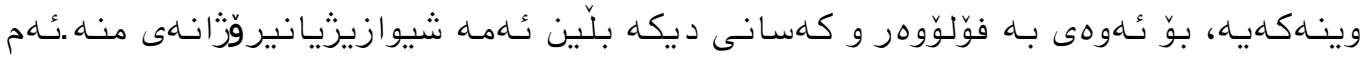

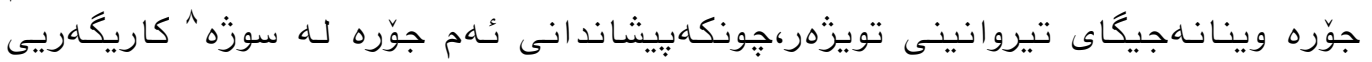

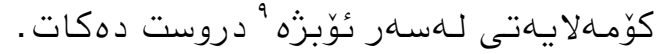

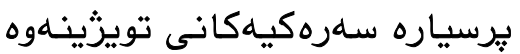

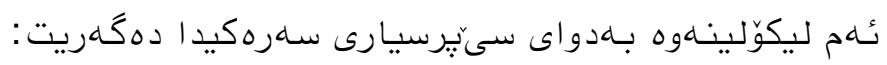

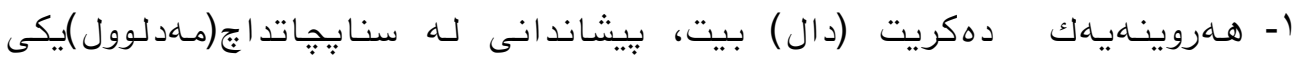

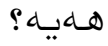

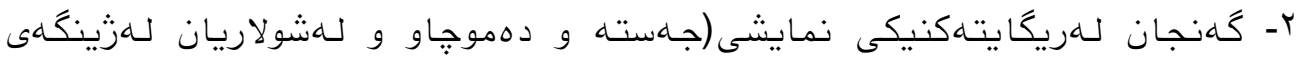

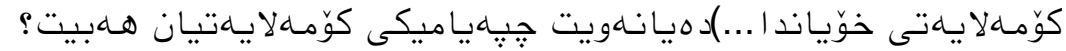

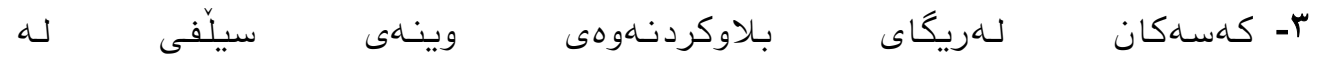

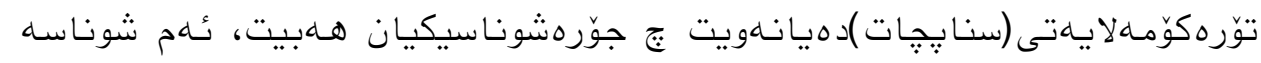

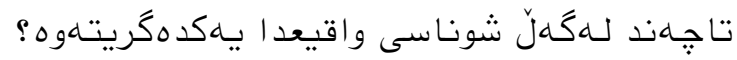

ناساندنى جهمكوكه سهره كييهكان

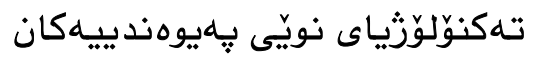

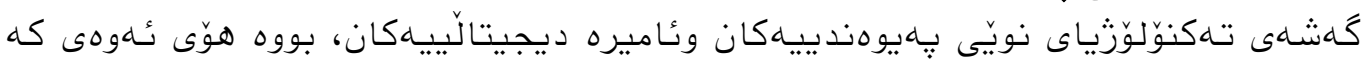

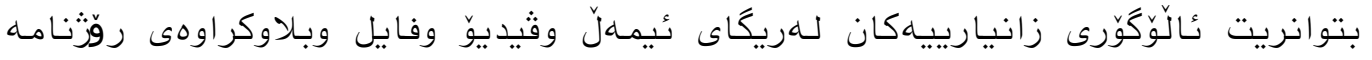

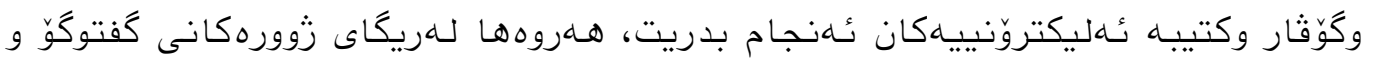

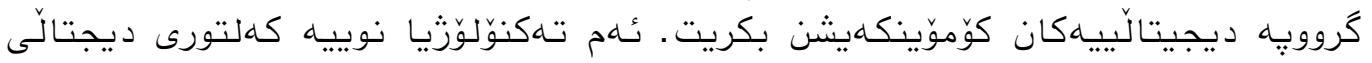

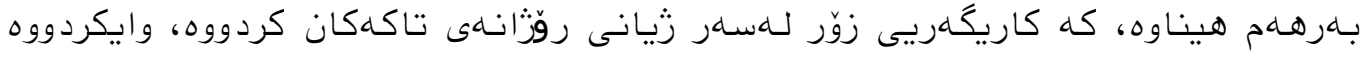

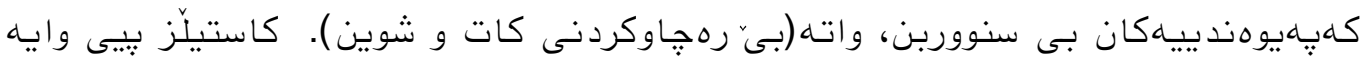

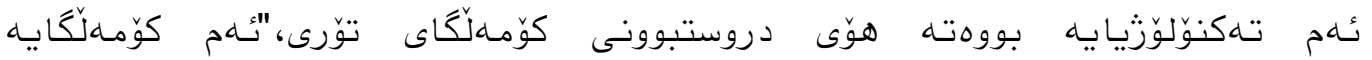

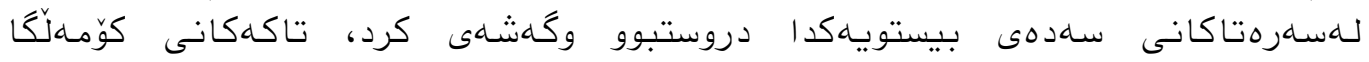

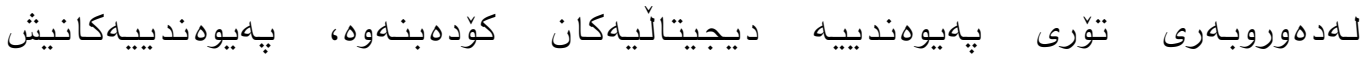

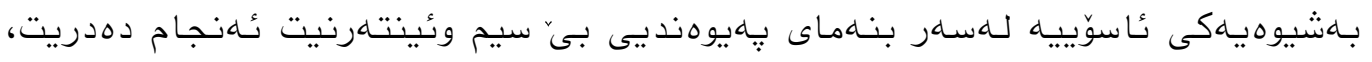

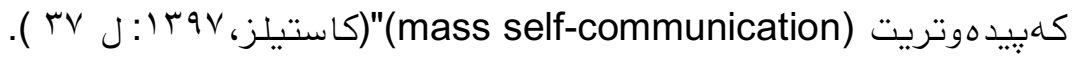

${ }^{8}$ Subject

${ }^{9}$ Object

DOI: $10.33193 / J A L H S S . r 8.11$ 
ising
هجلم الفنون والندب وعلوم اللإنسانيات واللاجتهـاع

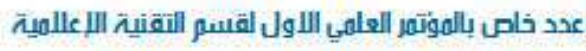

كلية التقنية الليدارية -جماهعة السليمانية التقنية

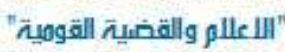

www.jalhss.com ISSN online: $2414-3383$ ISSN print $2616-3810$

2019 glo الع

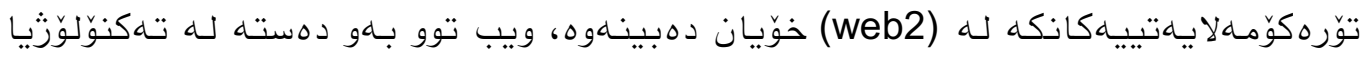

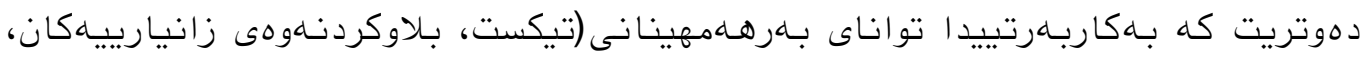

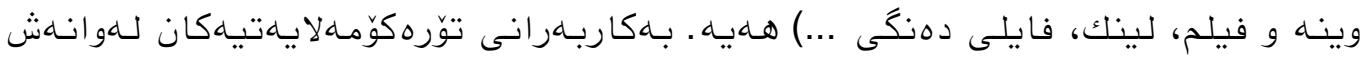

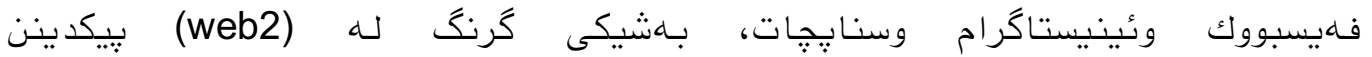

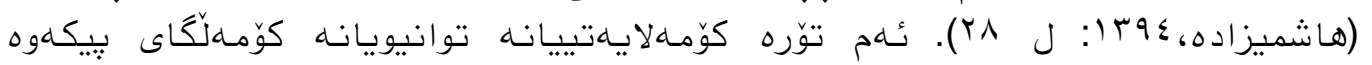

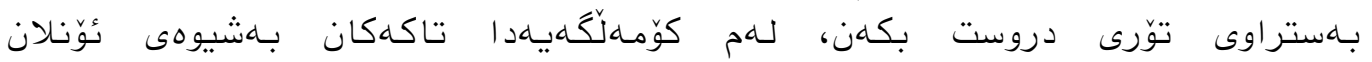

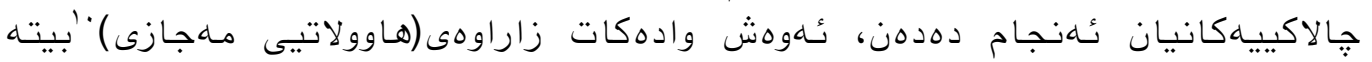

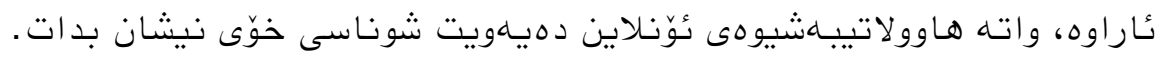

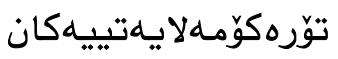

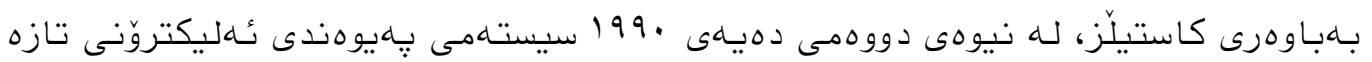

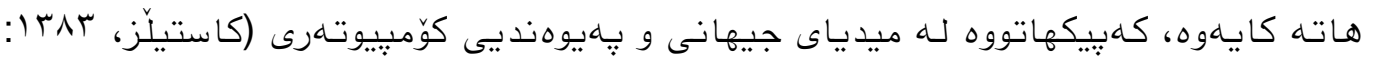

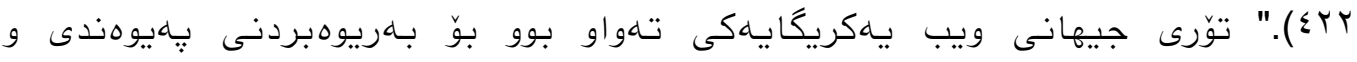

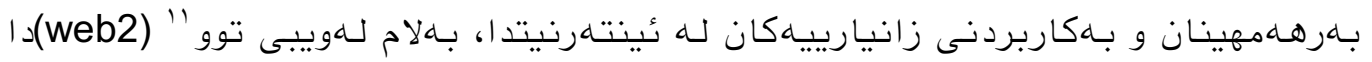

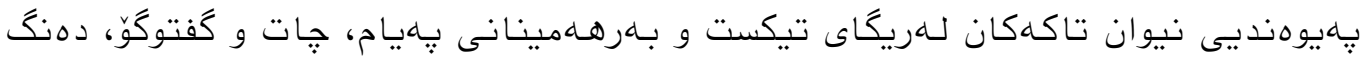

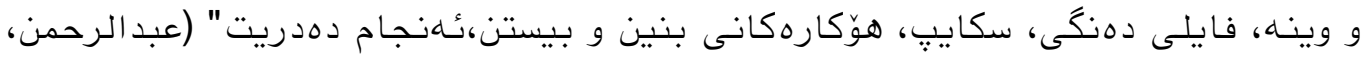
(10 (1) (1)

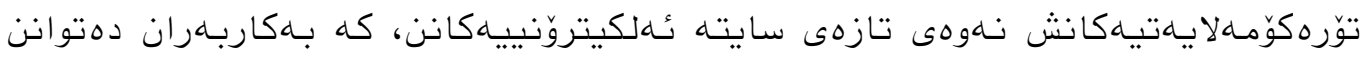

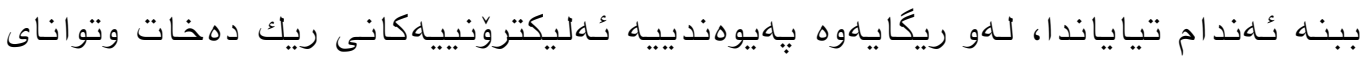

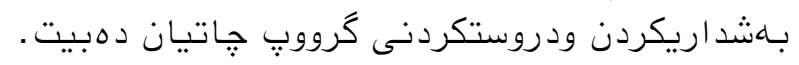
شونـاس و شوناسى يُوَنلاين

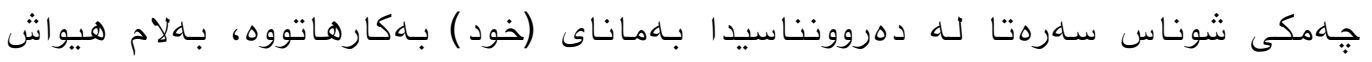

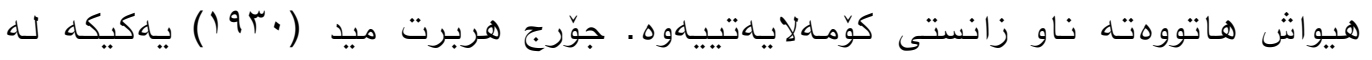

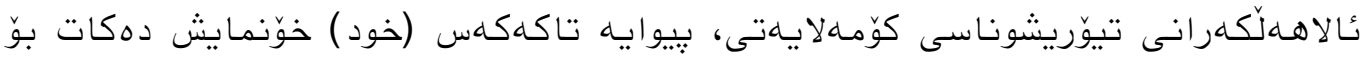

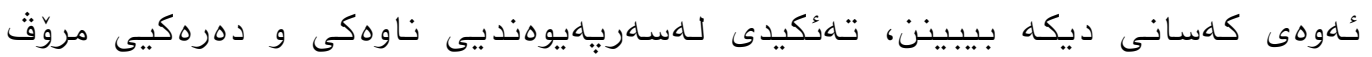

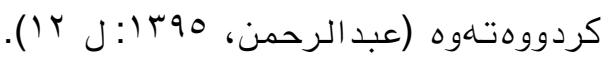

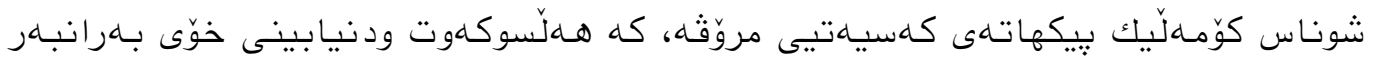

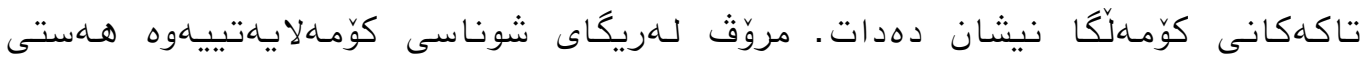

\section{${ }^{10}$ Cybercitizen}

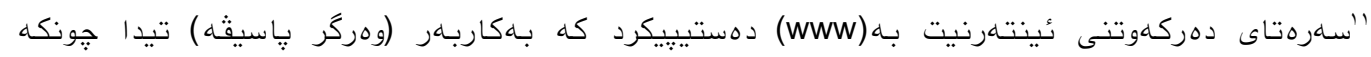

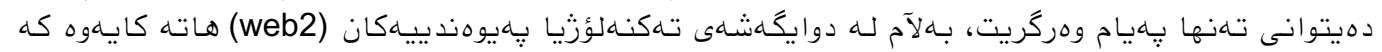

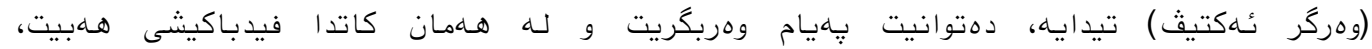

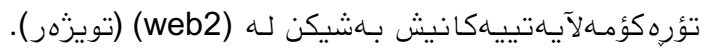




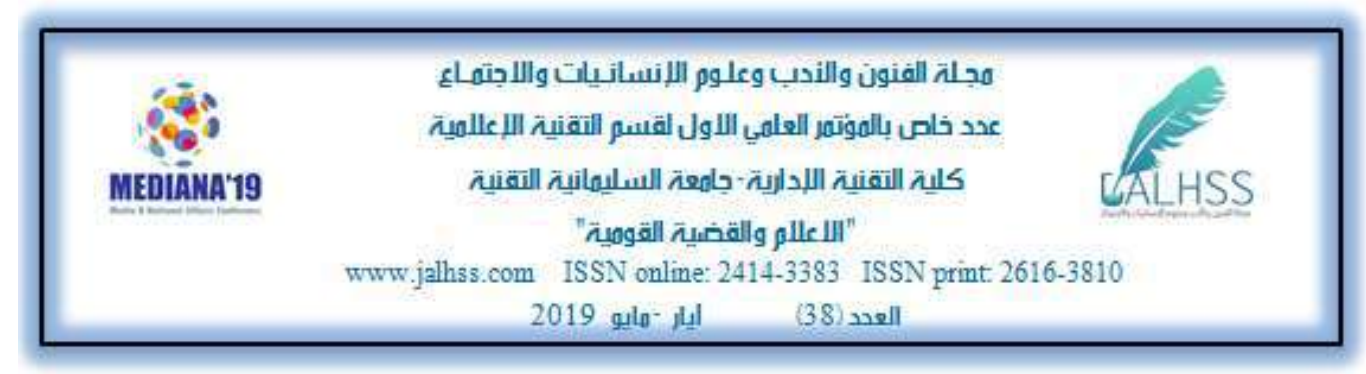

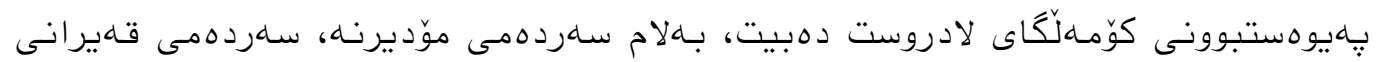

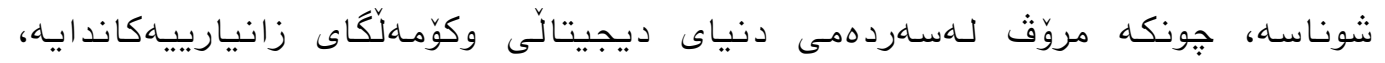

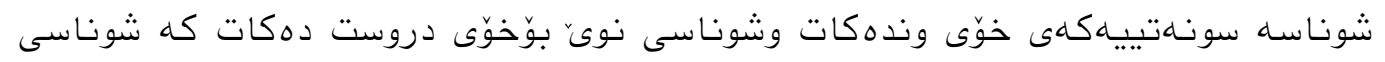
ئوّنلاينه .

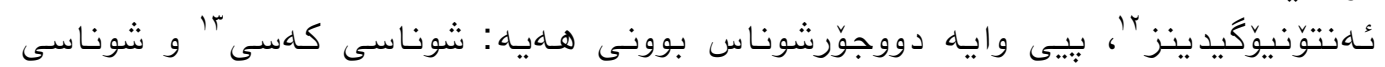

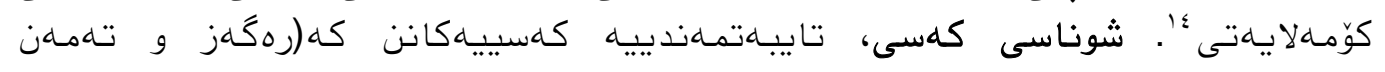

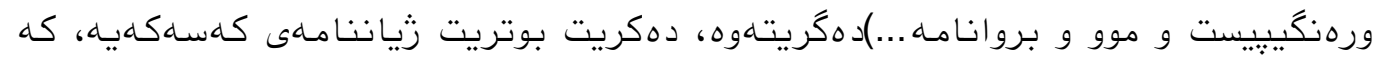

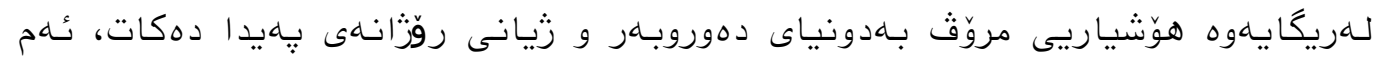

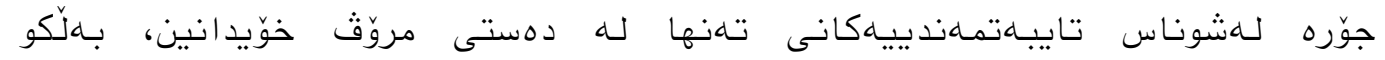

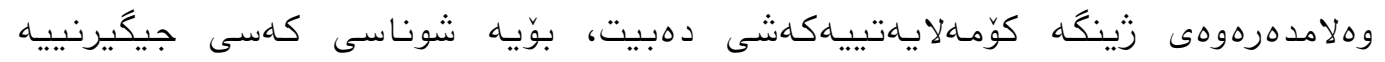

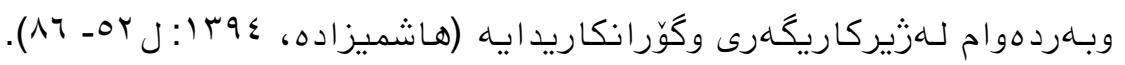

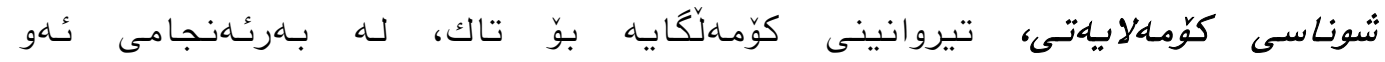

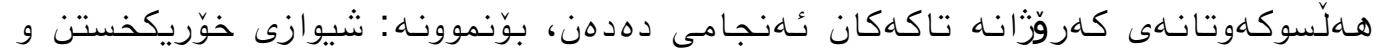

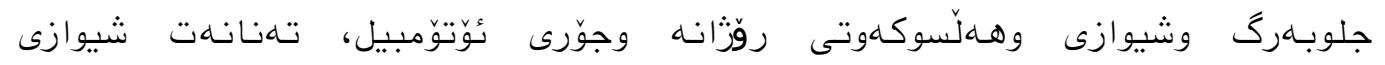

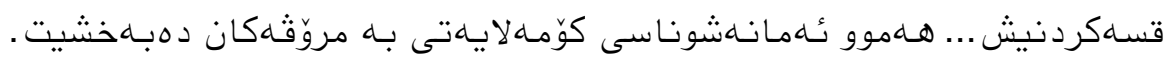

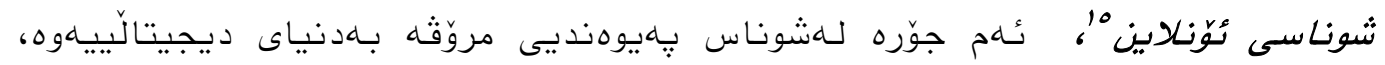

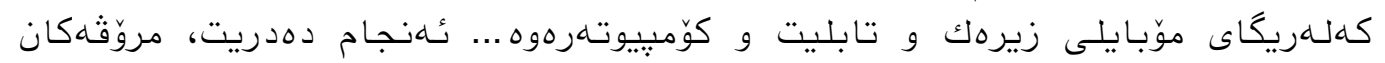

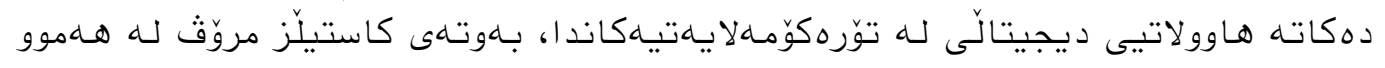

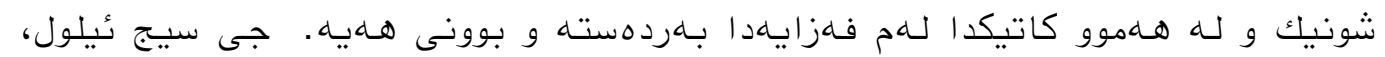

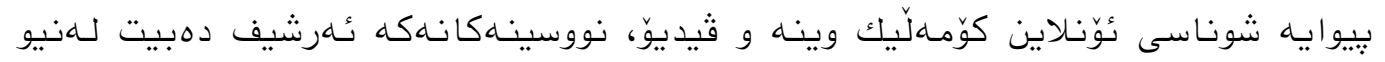

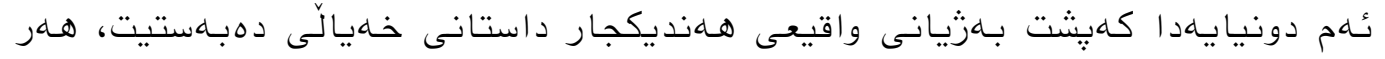

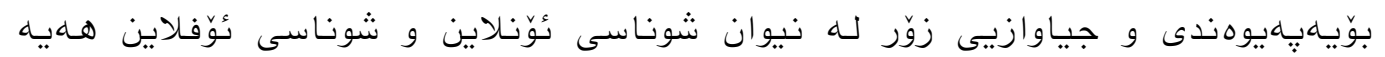

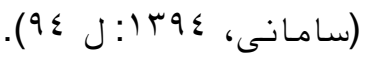

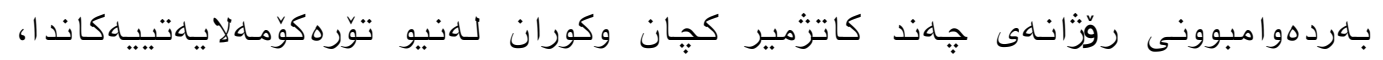

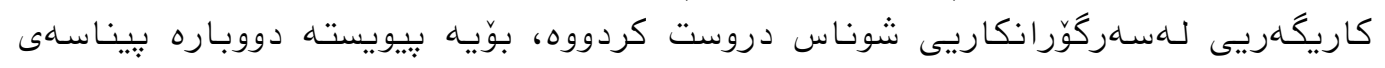

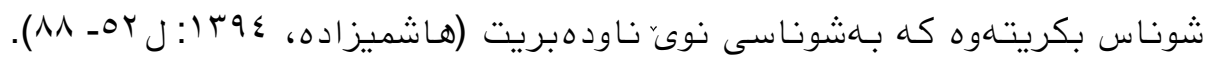

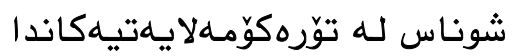

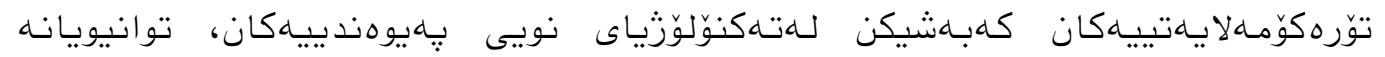

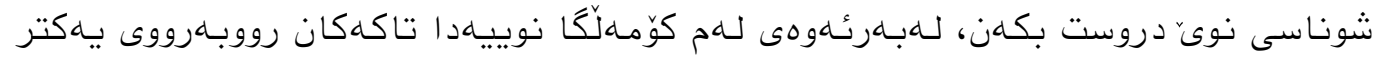

\footnotetext{
${ }^{12}$ Anthony giddens

${ }^{13}$ self-identity

${ }^{14}$ social Identity

${ }^{15}$ Identity on line
}

DOI: $10.33193 / J A L H S S . ~ r 8.11$ 
ising
هج الم الفنون والندب وعلوم اللإنسانيات واللاجتهاع

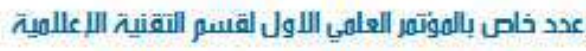

كلية التقنية اللداريت جامعة السليهانية التقنيت

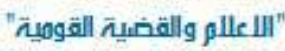

www.jalhss.com ISSN online: $2414-3383$ ISSN print $2616-3810$

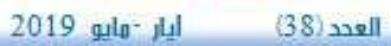

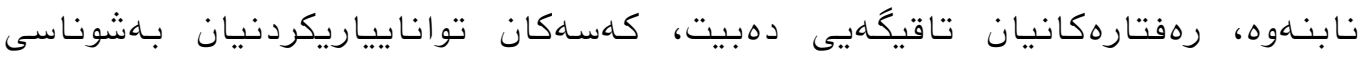

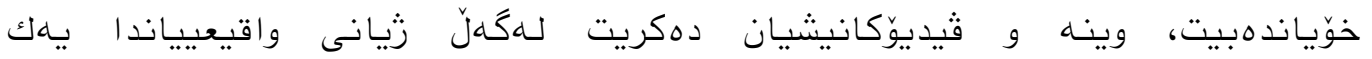

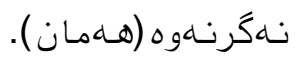

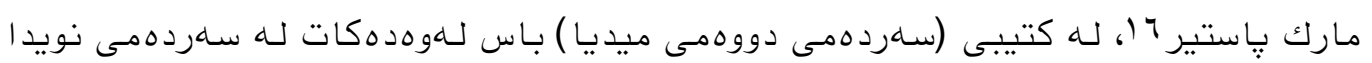

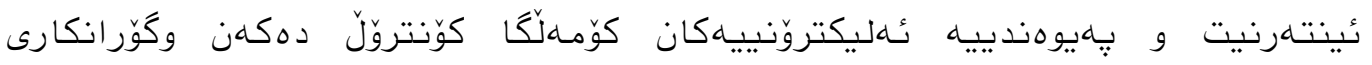

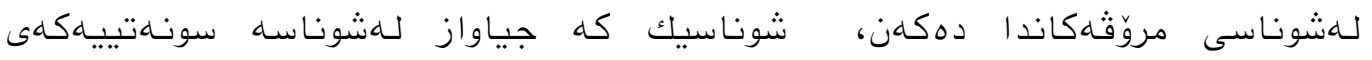

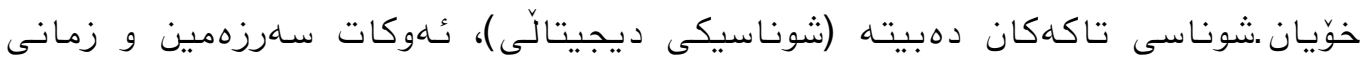

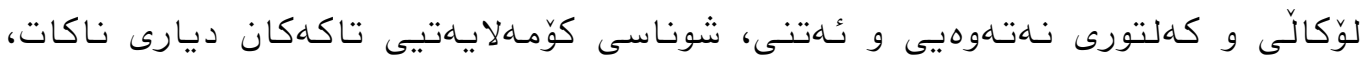

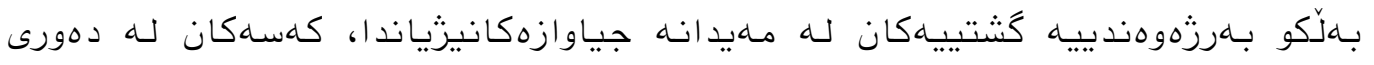

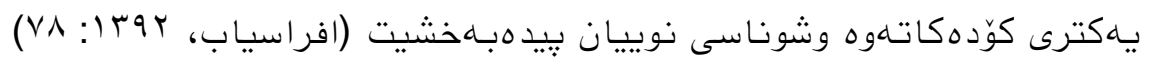

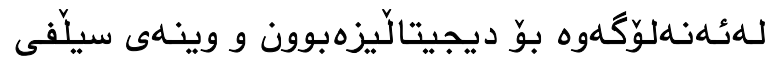

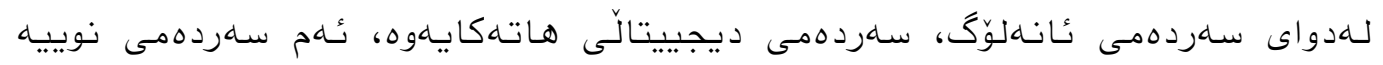

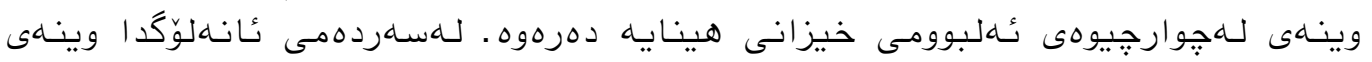

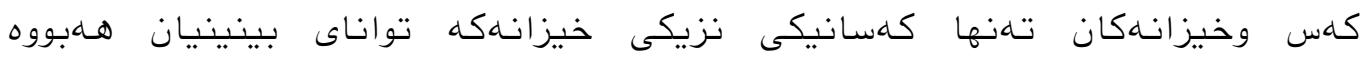

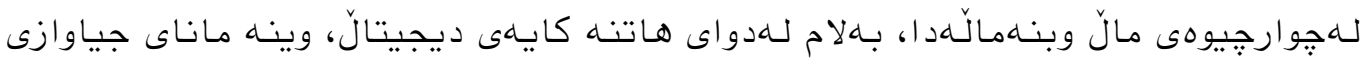

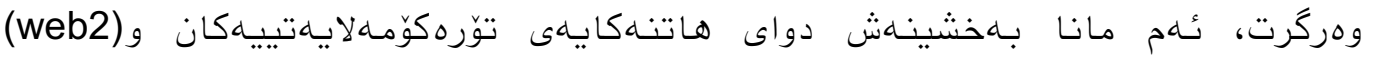

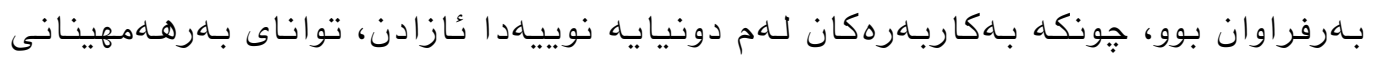

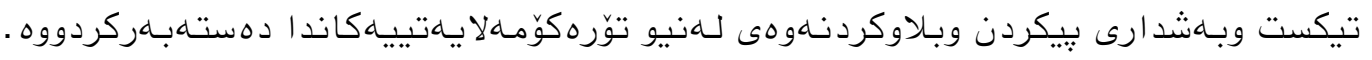

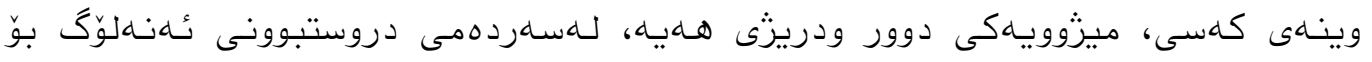

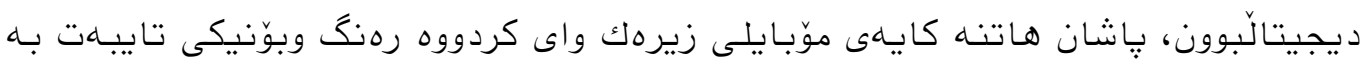

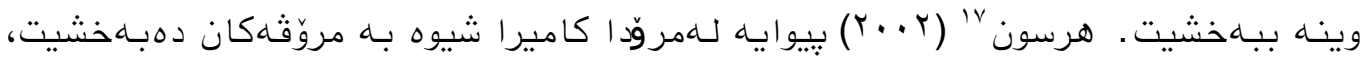

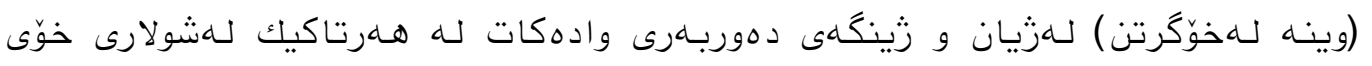

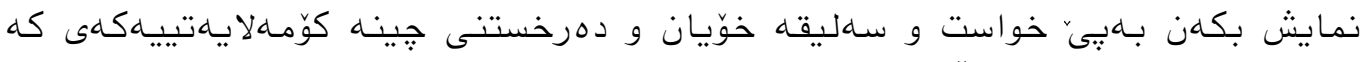

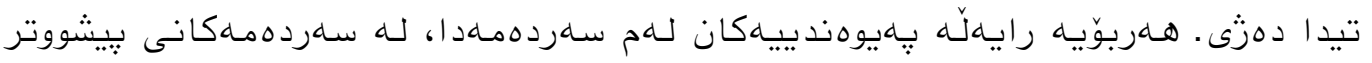

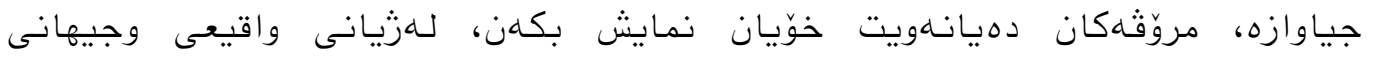

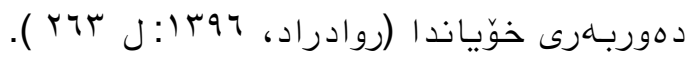

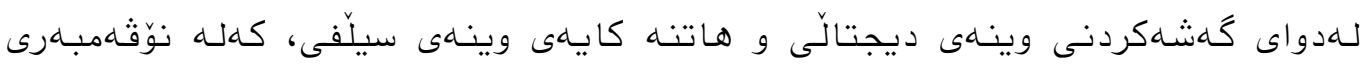

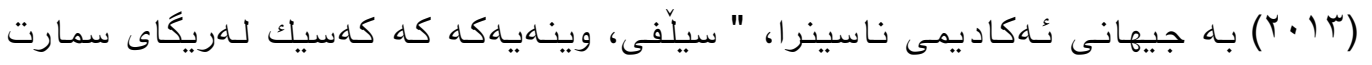

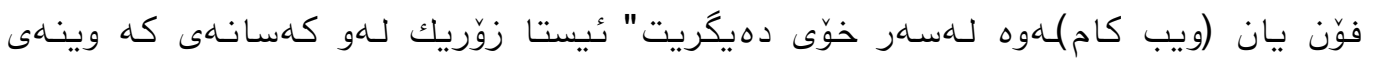

16Mark Batterson

${ }^{17}$ Herson capri

DOI: $10.33193 / J A L H S S . ~ r 8.11$ 


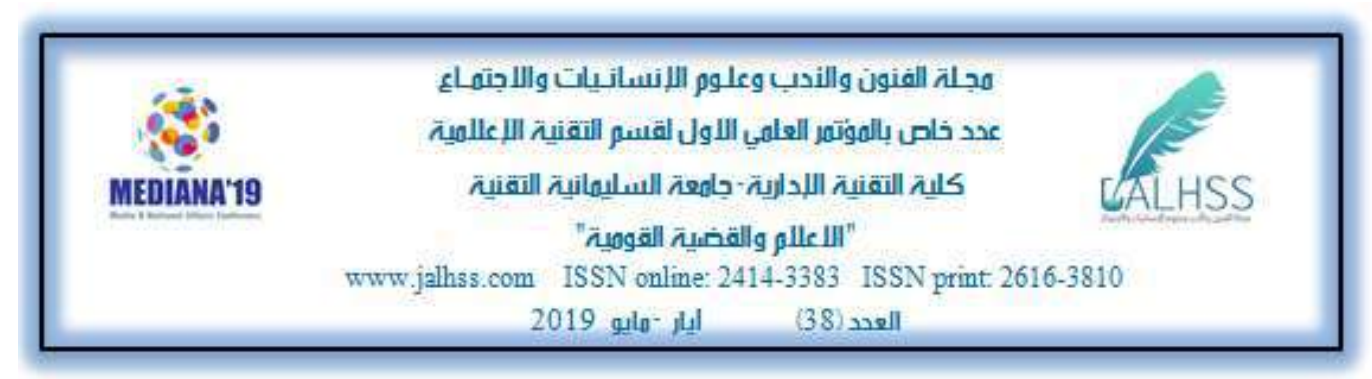

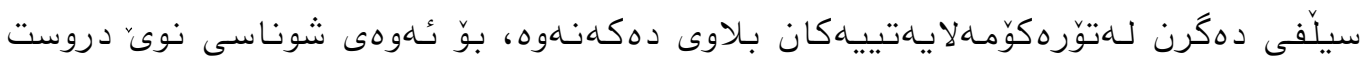

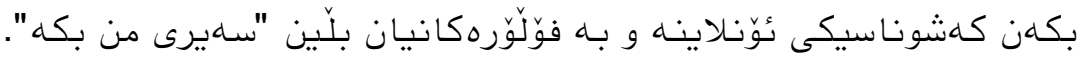

\section{ميتوّدنامهى تويزينهوه}

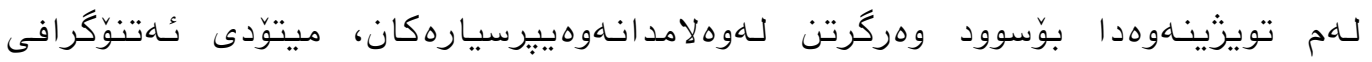

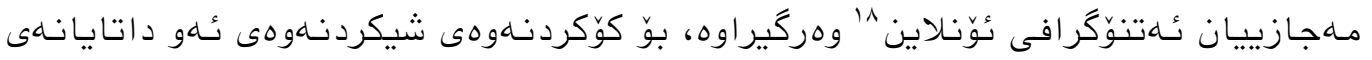

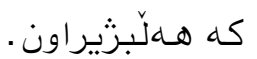

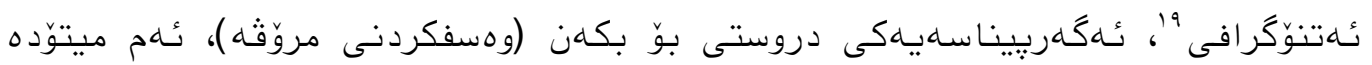

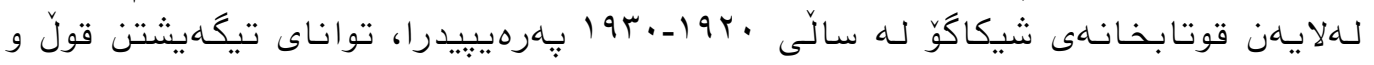

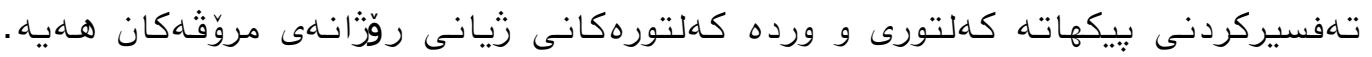

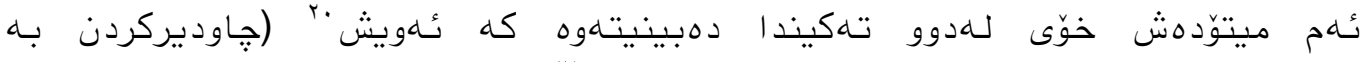

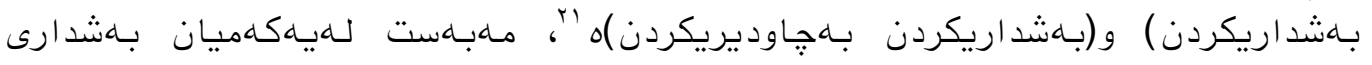

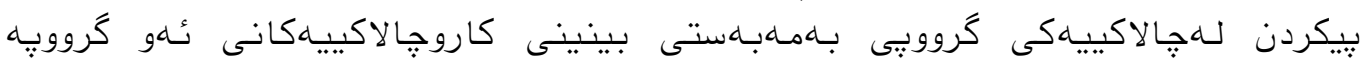

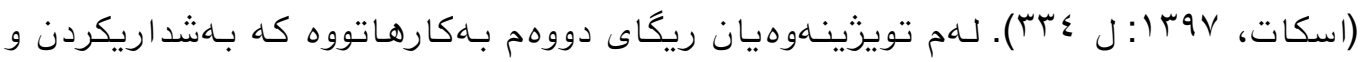

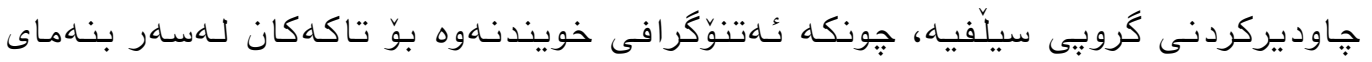

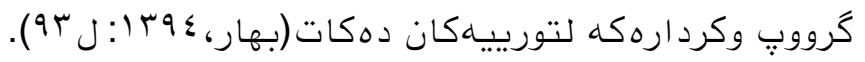

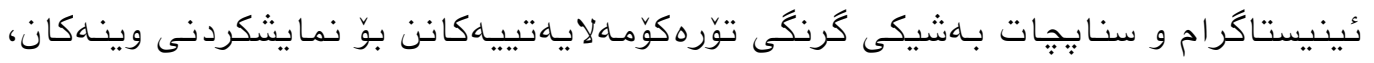

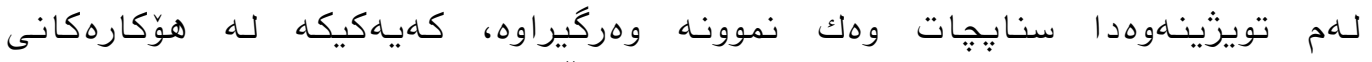

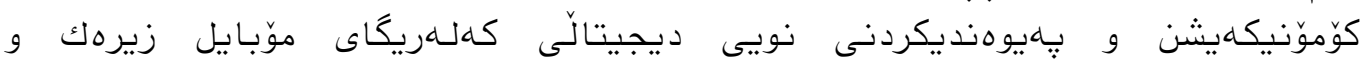

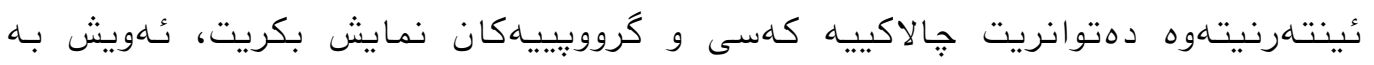

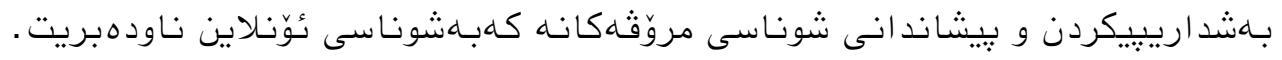

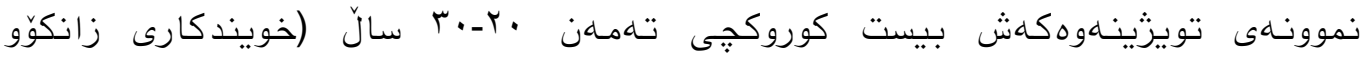

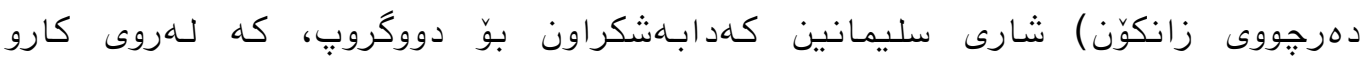

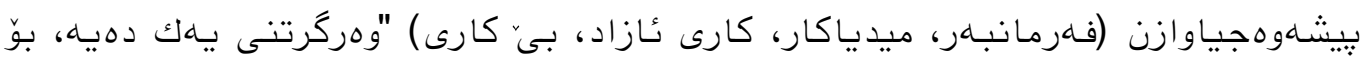

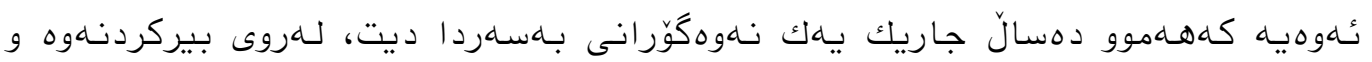

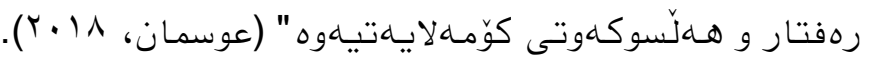

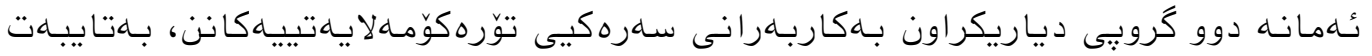

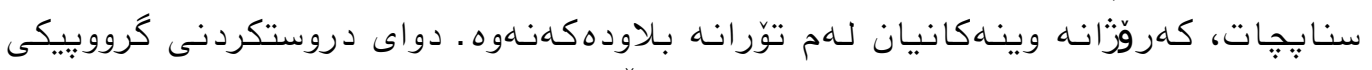

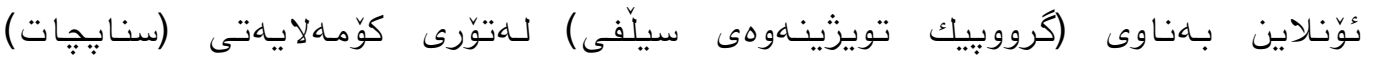

${ }^{18}$ Online Ethnography

${ }^{19}$ Anthropology

${ }^{20}$ observation participation

${ }^{21}$ participation observation 
ising
هجلة الفنون والندب وعلوم اللإنسانيات واللاجِمهاع

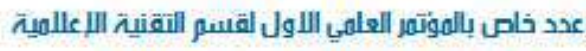

كلية التقنية اللدازية -جاهعت السليهانية التهنيت

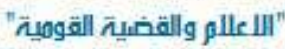

www.jalhss.com ISSN online: $2414-3383$ ISSN print $2616-3810$

2019 glo الع

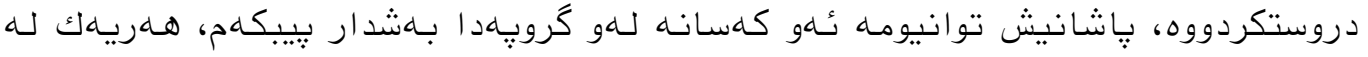

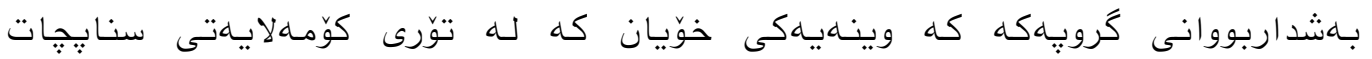

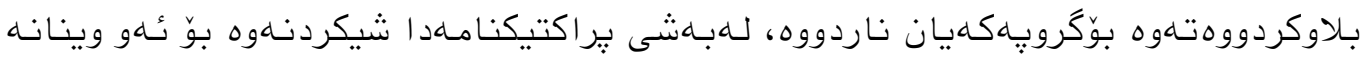

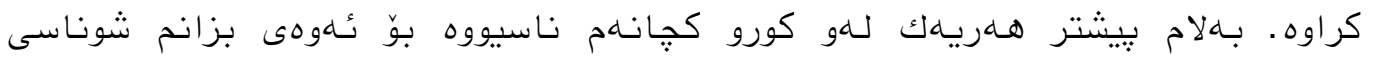

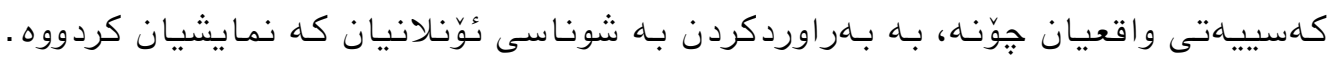

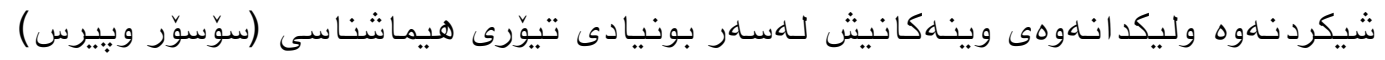

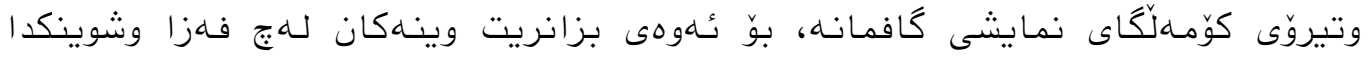

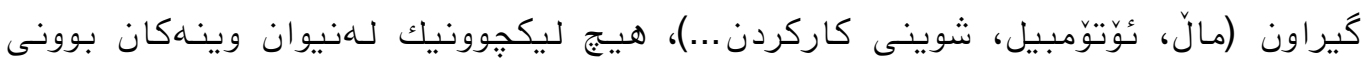

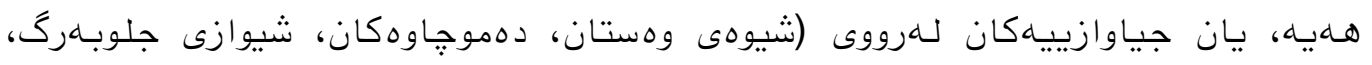

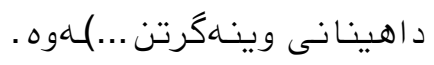

\section{تيَوْرنامهـ}

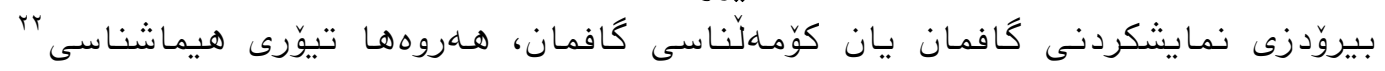

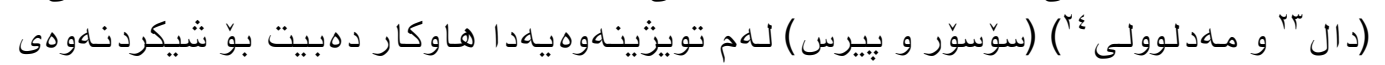

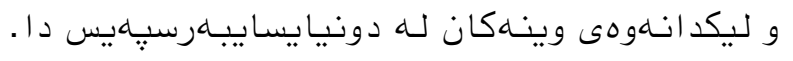

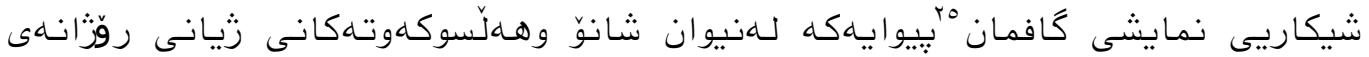

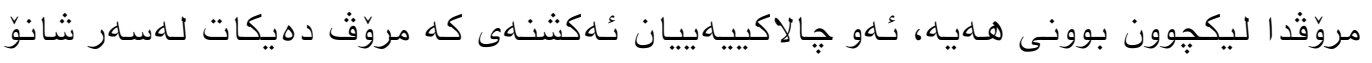

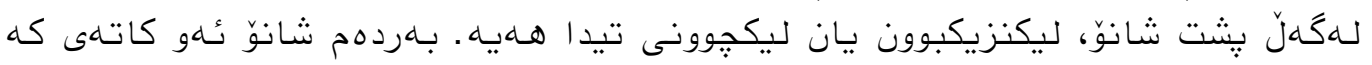

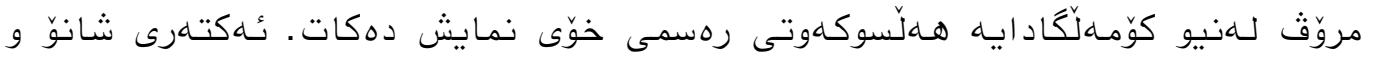

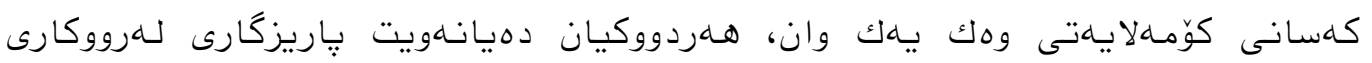

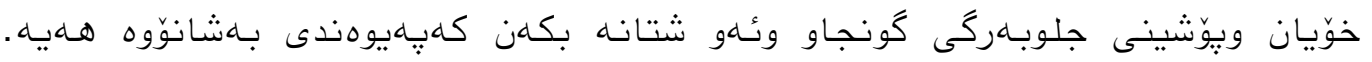

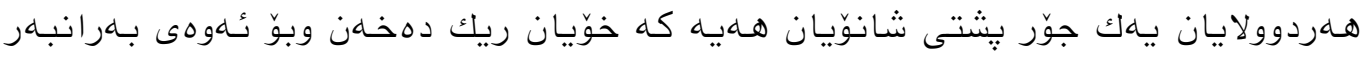

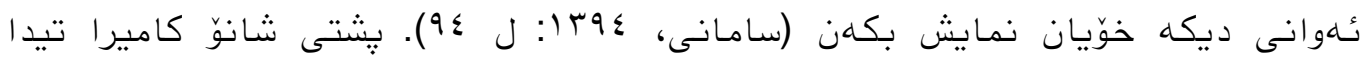

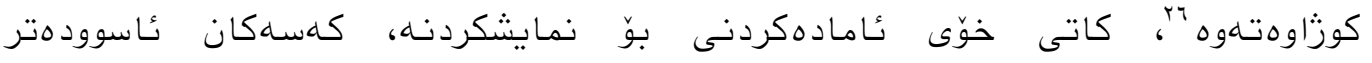

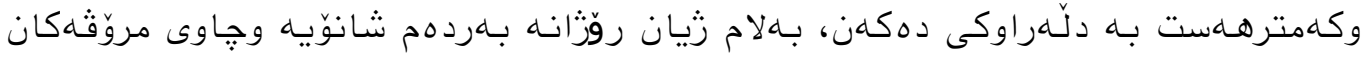

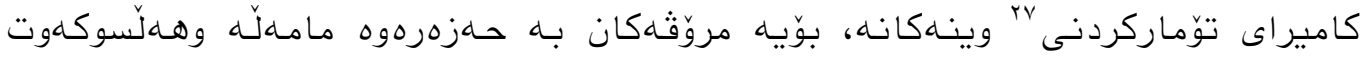

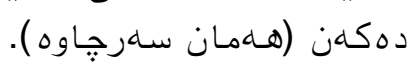

\footnotetext{
${ }^{22}$ Semiology

${ }^{23}$ symbol

${ }^{24}$ Sense

${ }^{25}$ Dramaturgical analysis

${ }^{26}$ Off record

${ }^{27}$ On record
} 


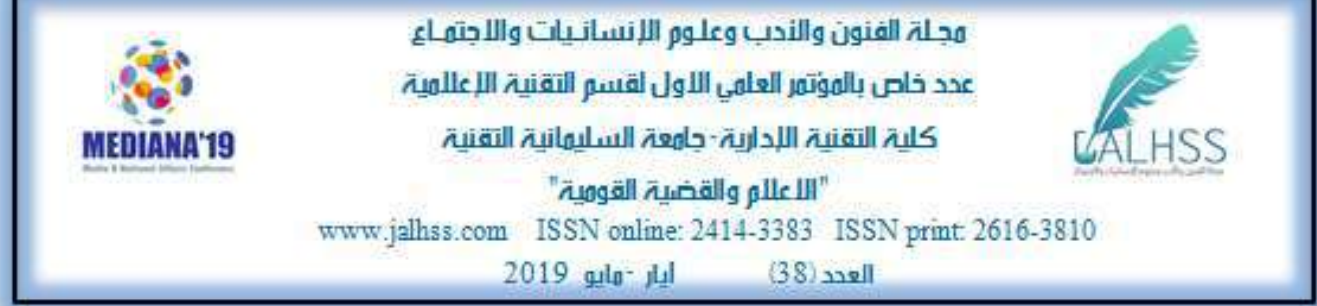

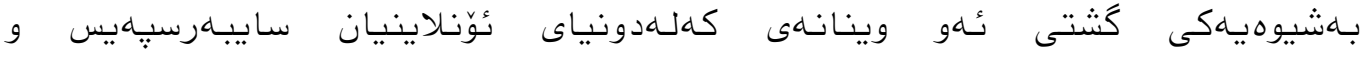

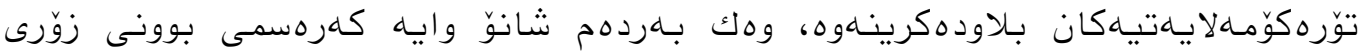

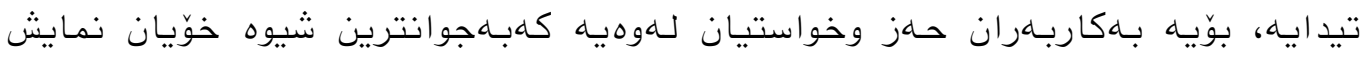

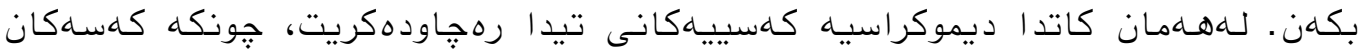

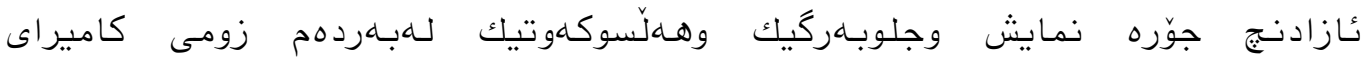

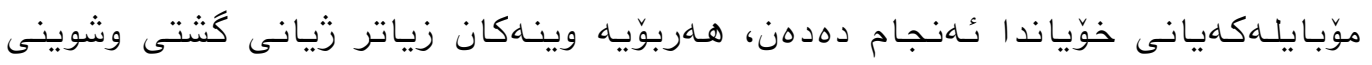

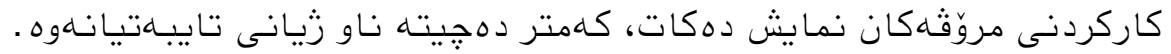

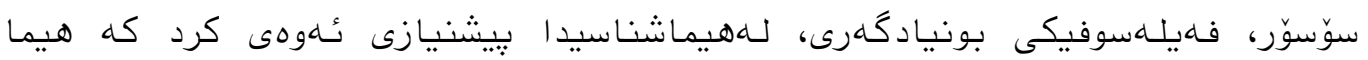

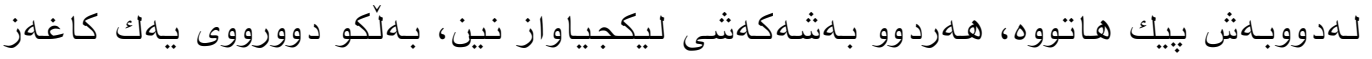

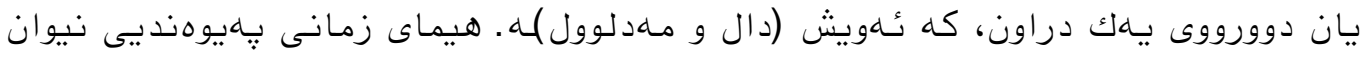

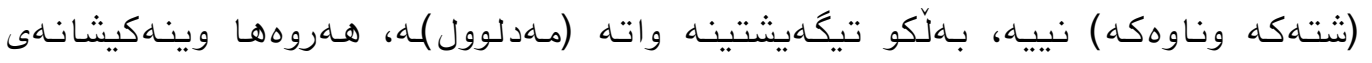

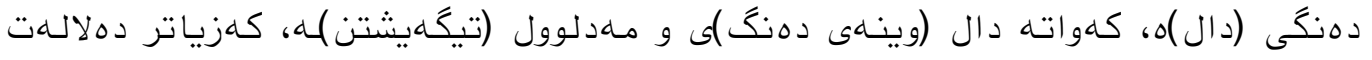

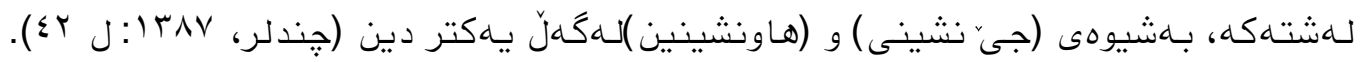

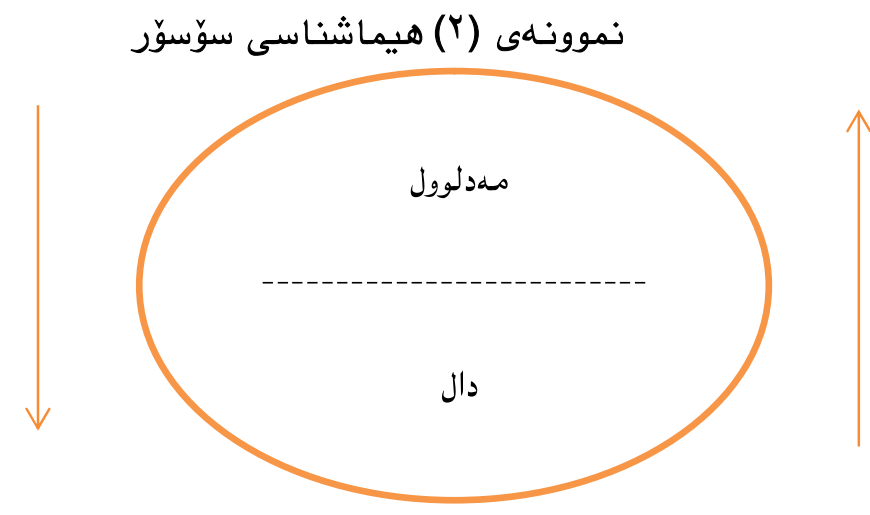

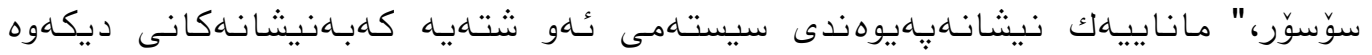

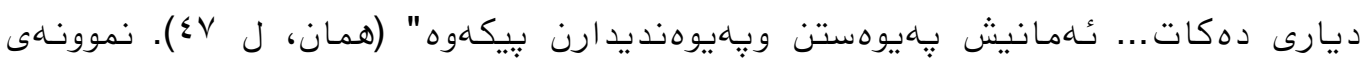

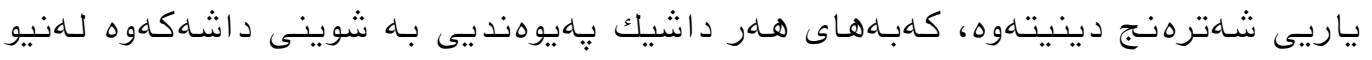

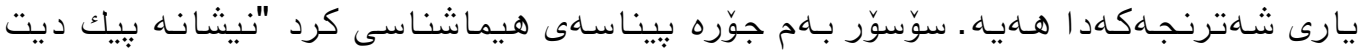

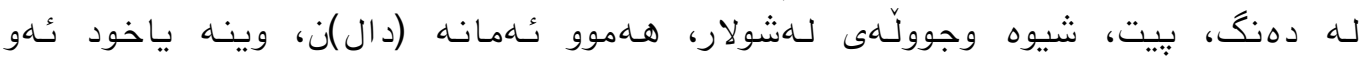

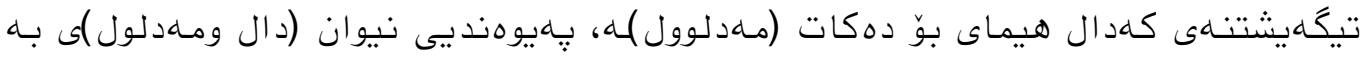

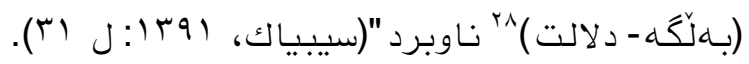

${ }^{28}$ sifnification

DOI: $10.33193 / J A L H S S . r 8.11$ 


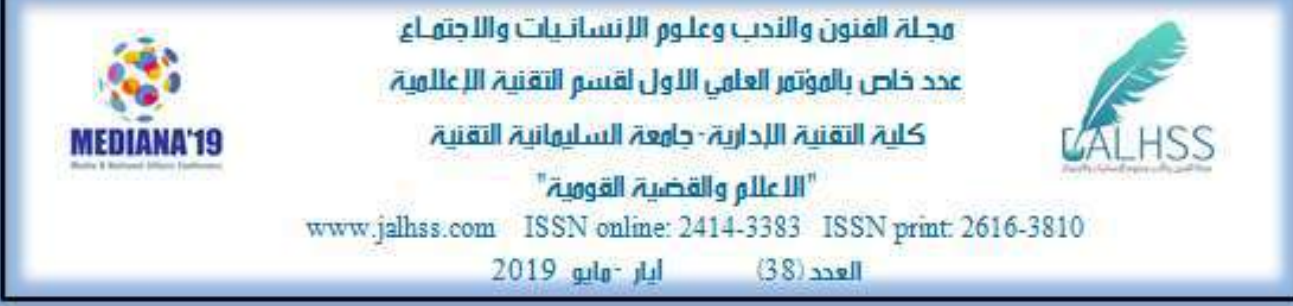

بوّ نموونه: دهنگ و وينه وشيوهى نووسينى يهك وشه للهسهر كاغهز، (داله)، (مهدلوول)

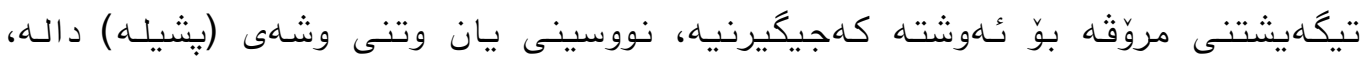

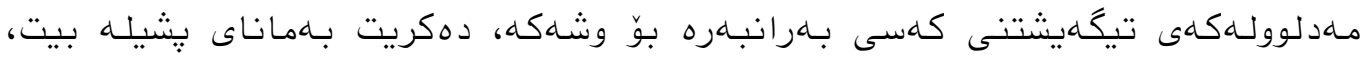

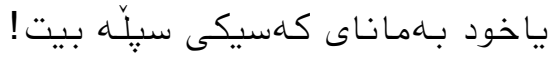

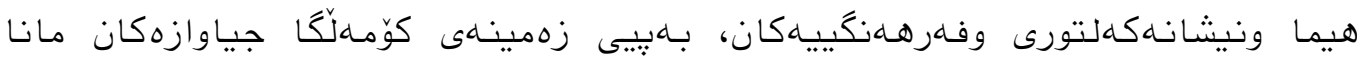

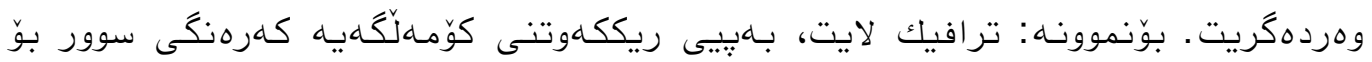

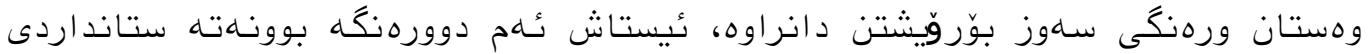

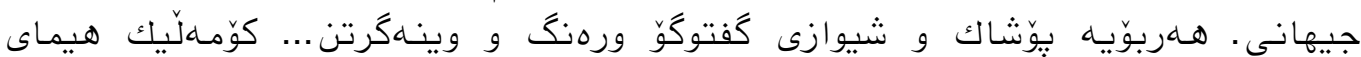

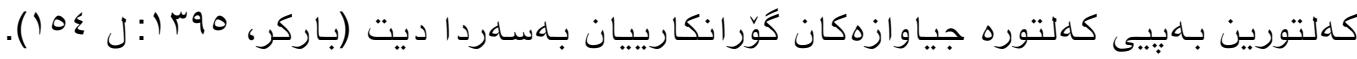

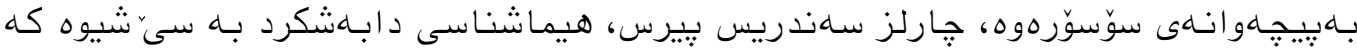

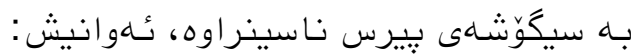

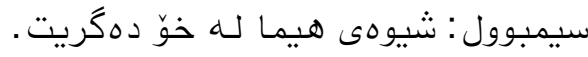

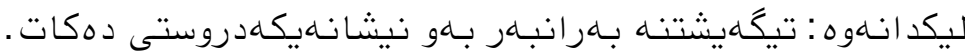

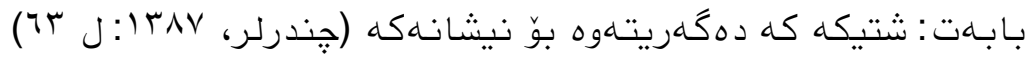

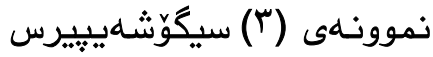

B

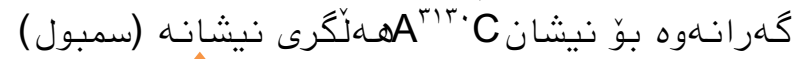

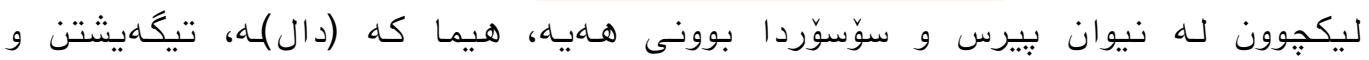

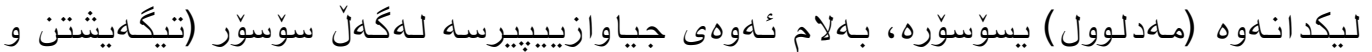

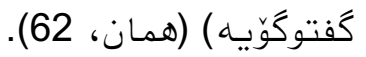

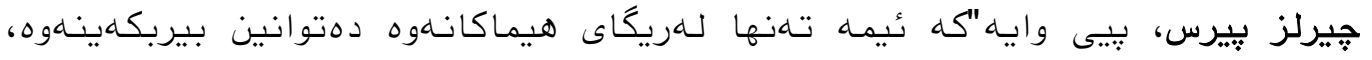

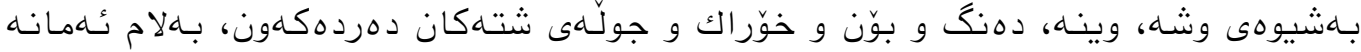

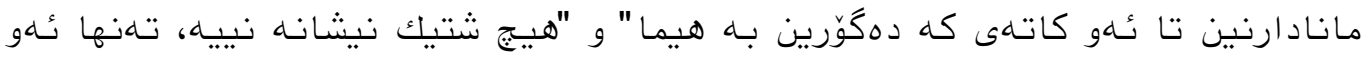

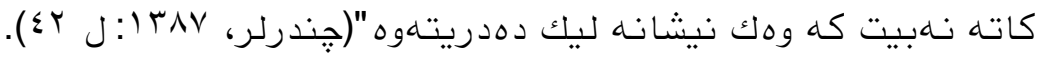

\footnotetext{
${ }^{29}$ interparent

${ }^{30}$ object

${ }^{31}$ Sign
} 


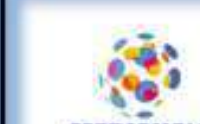

MEDIĀMA'19
هجِلة الفنون والندب وعلوم اللإنسانيات واللاجتهـاع

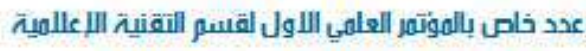
كلية التقنية اللدازية جاهعت السليهانية التقنيت

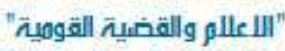

www.jalhss.com ISSN online: $2414-3383$ ISSN print $2616-3810$

\section{9 gll (38)}

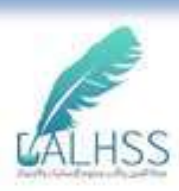

SS

$$
\text { جوّرهكانى هيماشناسى كوّمهلايهنى }
$$

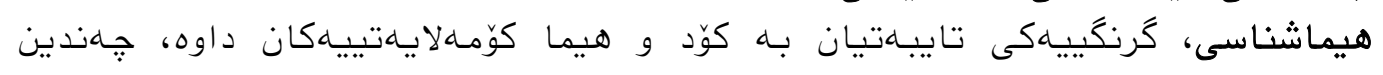

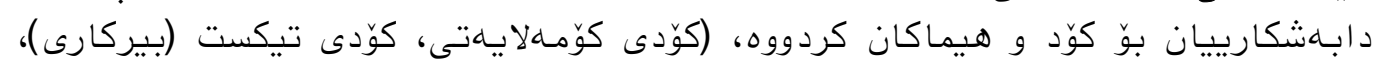

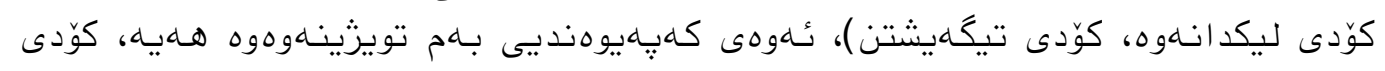

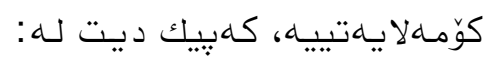

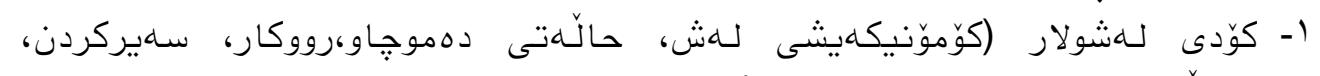

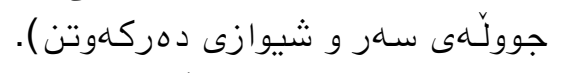

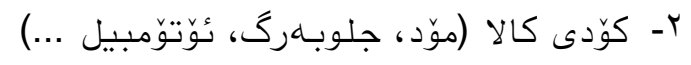

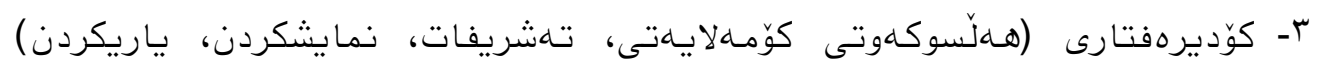

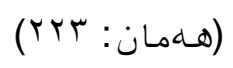

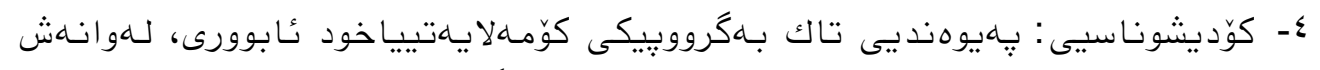

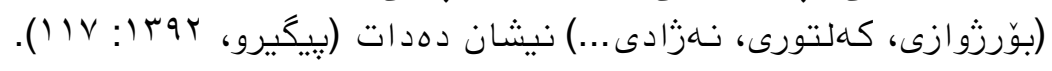

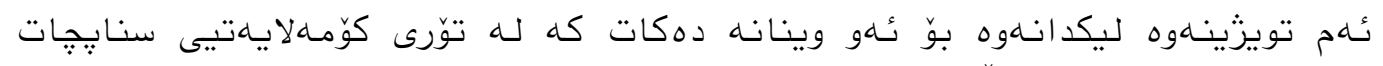

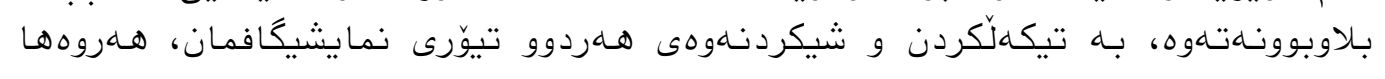

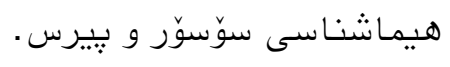

\title{
براكتيكنامه
}

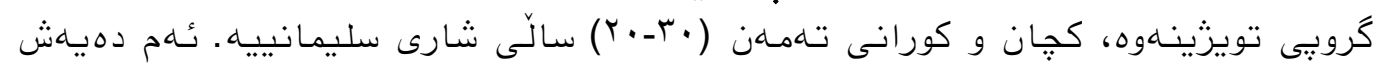

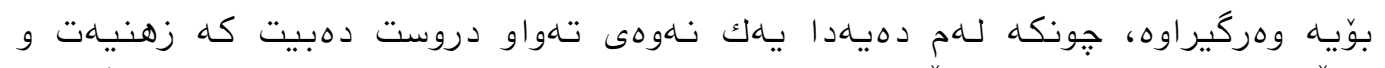

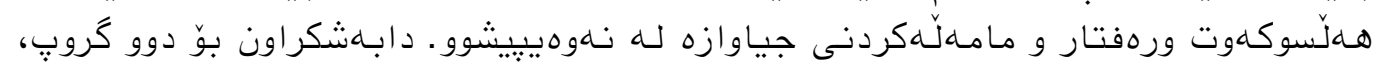

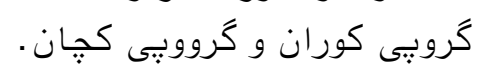

\author{
كروبيnيهكهم: وينهكانى كجان

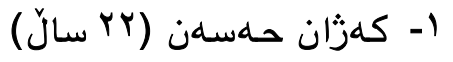 \\ شيكارى هاونشينى rr:
}

${ }^{32}$ Collaborative analysis

DOI: $10.33193 / J A L H S S . ~ r 8.11$ 

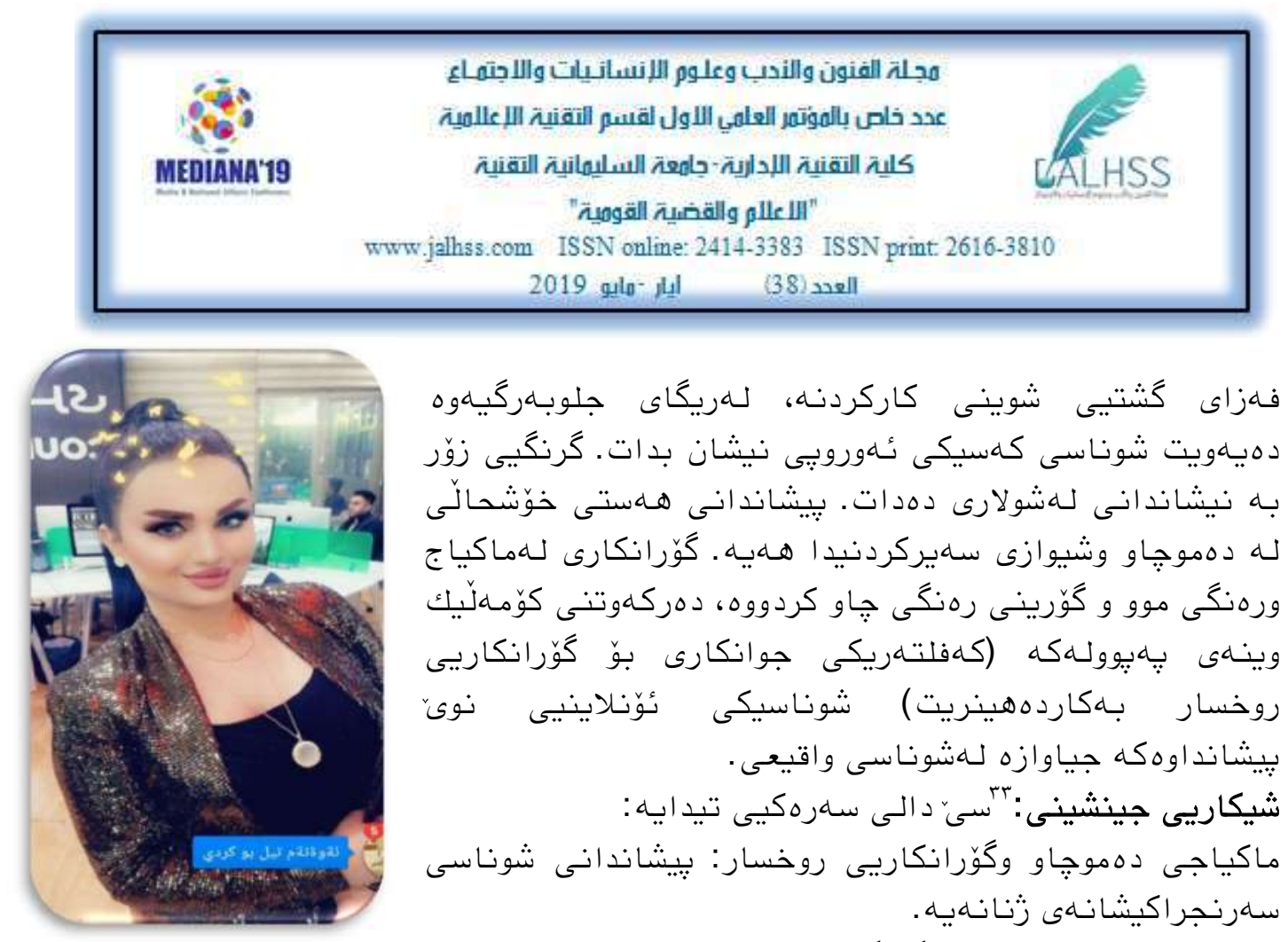

فـهزاى كشتيى شوينى كاركردنه، لـهريگاى جلوبهارگيهوه

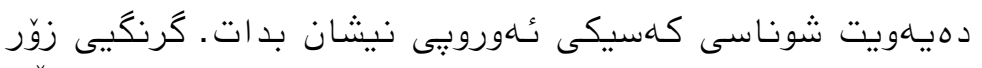

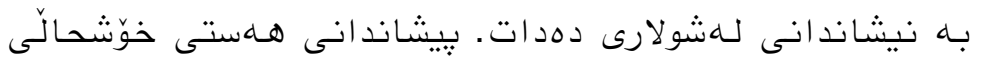

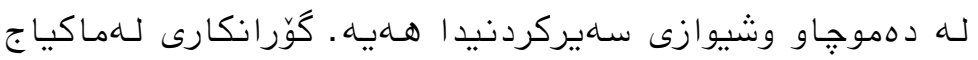

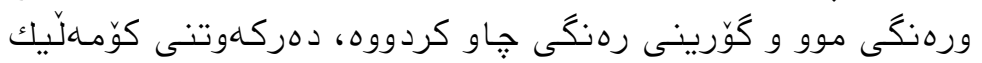

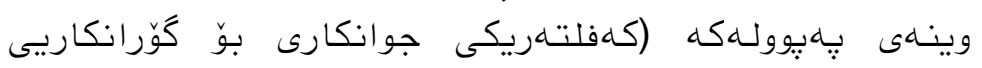

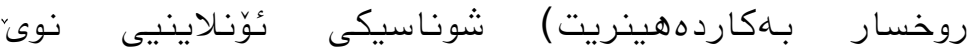

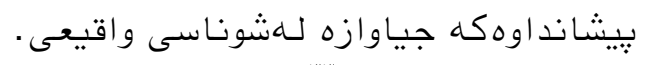

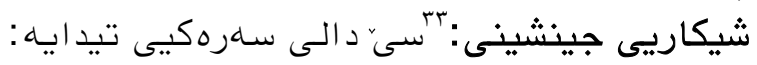

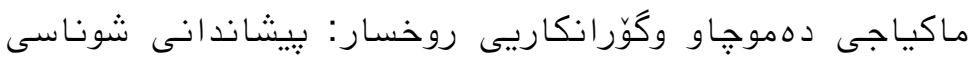

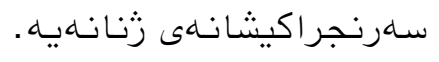

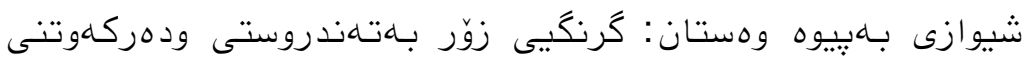

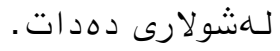

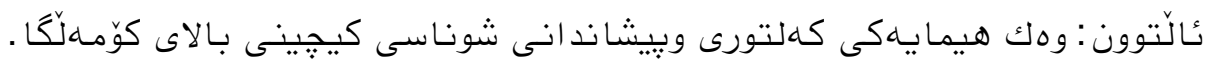

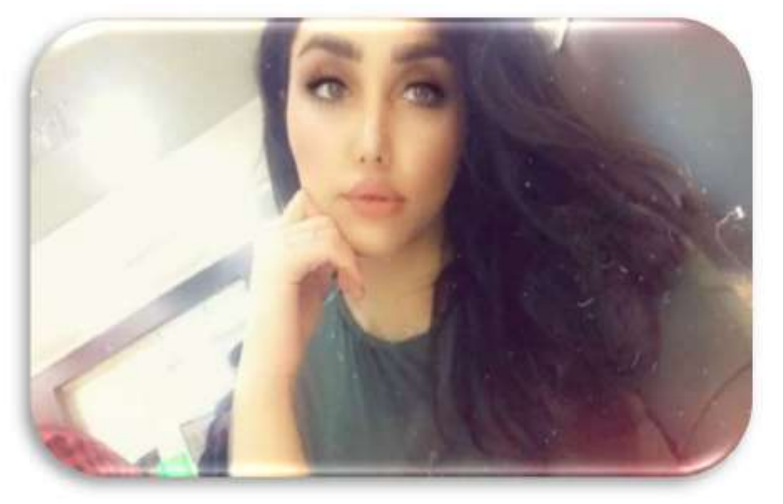

$$
\begin{aligned}
& \text { r- زالّهرهسوولا (0 ب سالّ) } \\
& \text { شيكارى هاونشين: }
\end{aligned}
$$

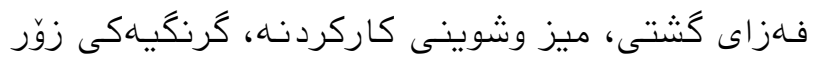

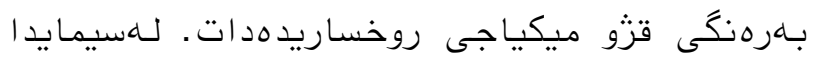

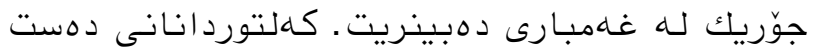

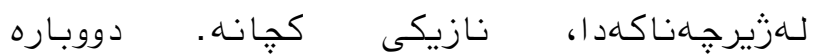

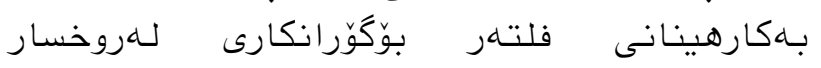

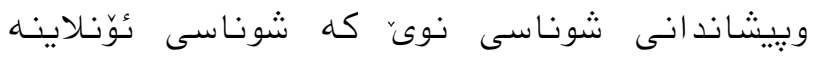

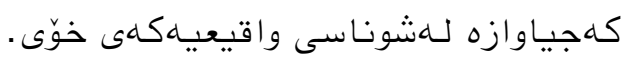

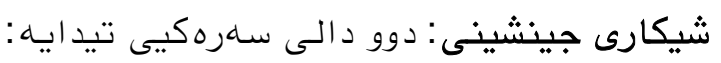

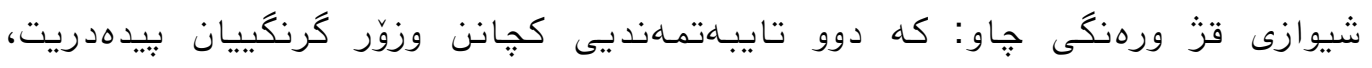

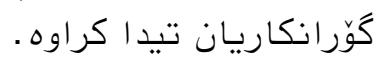

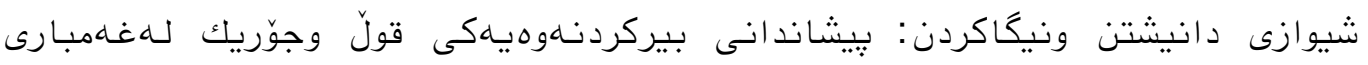
له لهروخسارد ا دهبينريت.

${ }^{33}$ Substitution Analysis 

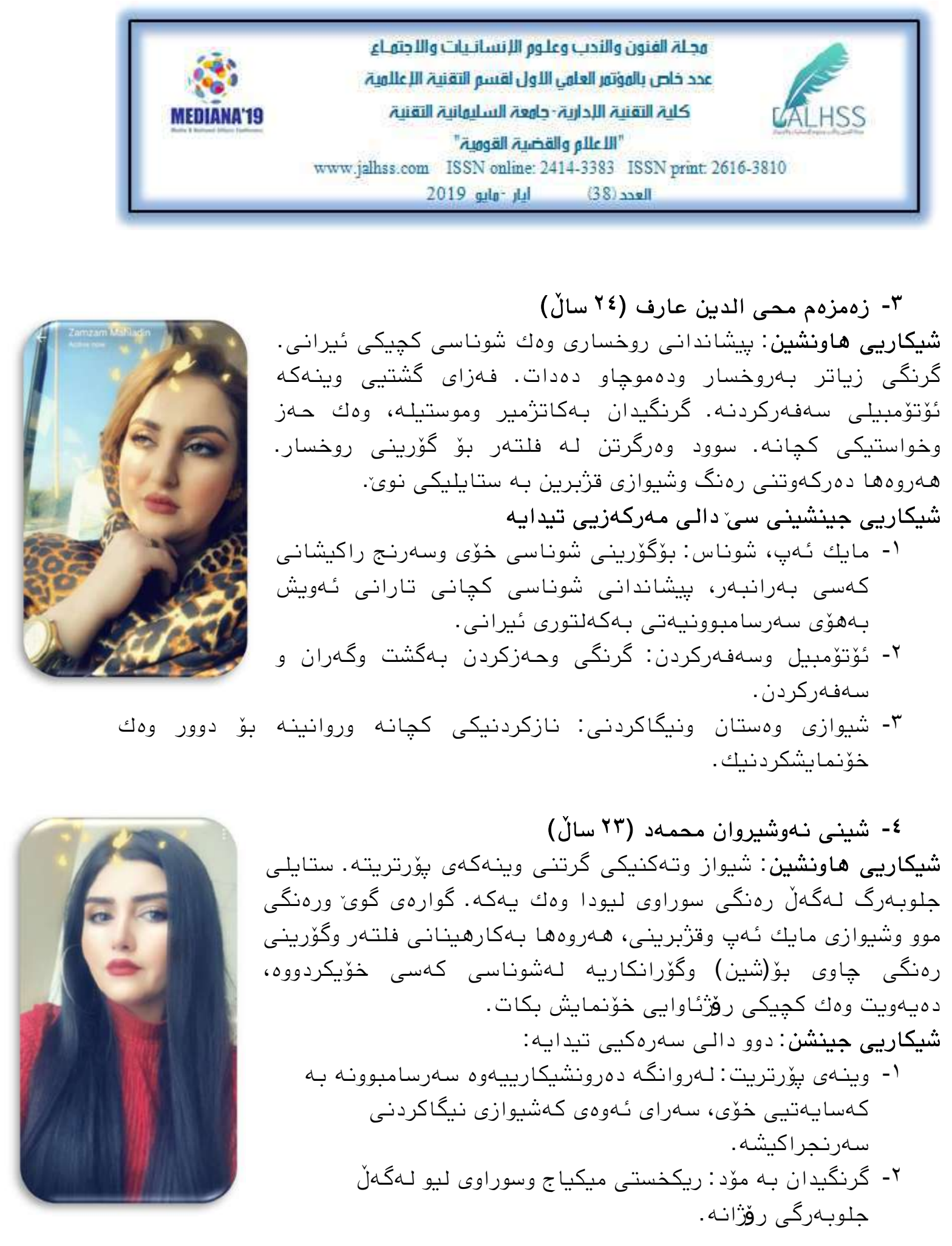

DOI: $10.33193 / J A L H S S . r 8.11$ 

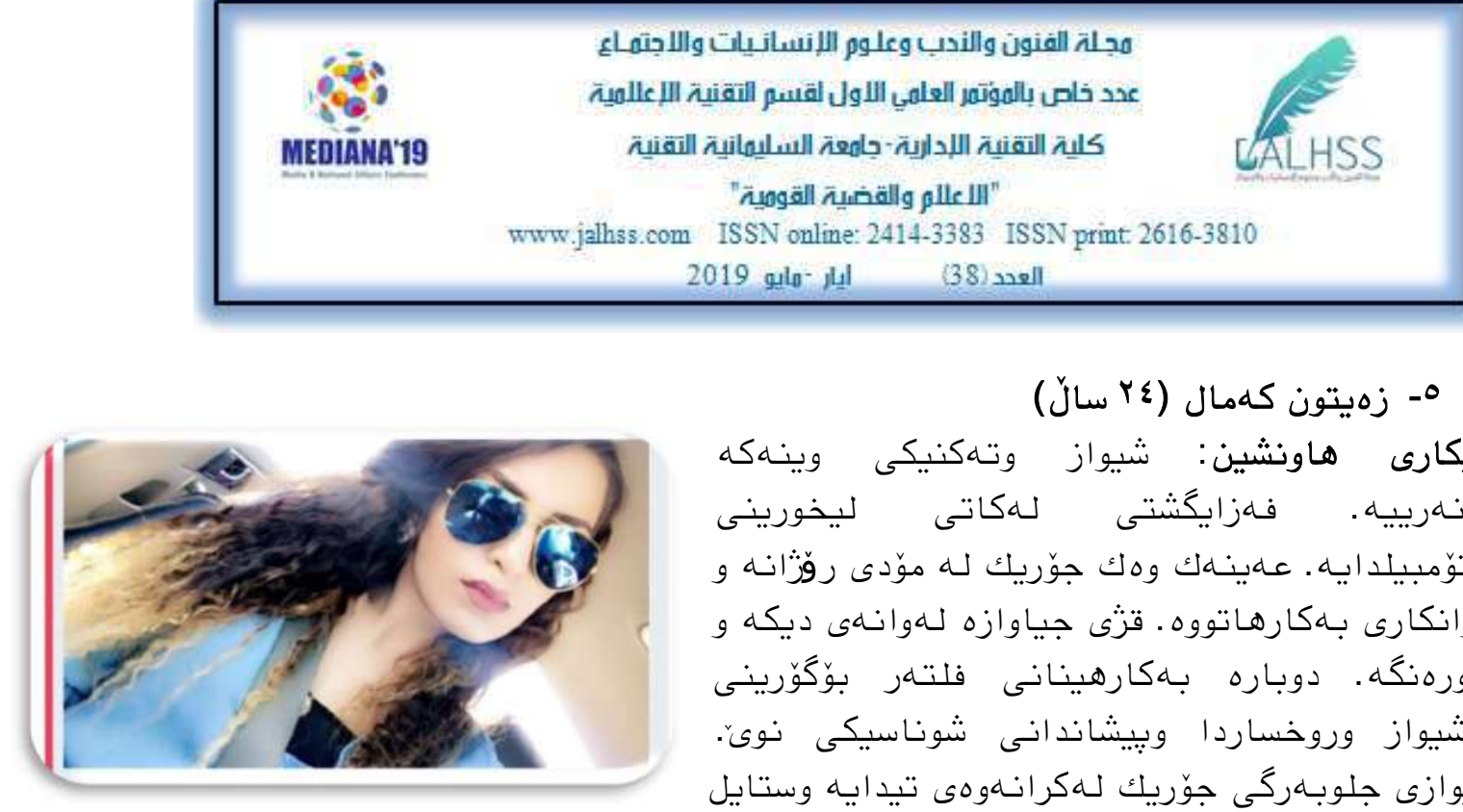

$$
\begin{aligned}
& \text { 0- زهيتون كهمال (ع سالّ) }
\end{aligned}
$$

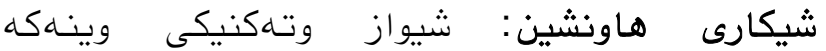

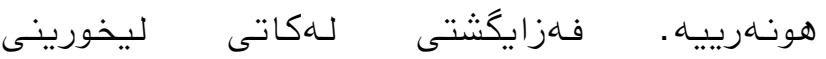

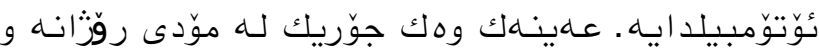

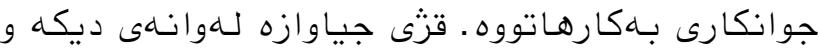

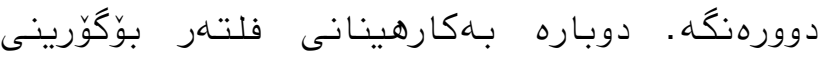

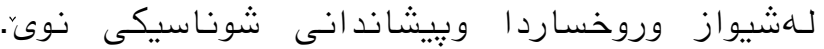

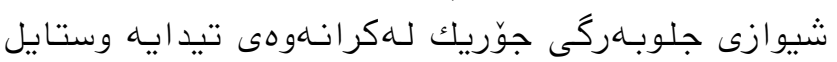

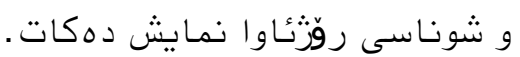

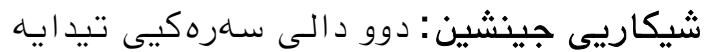

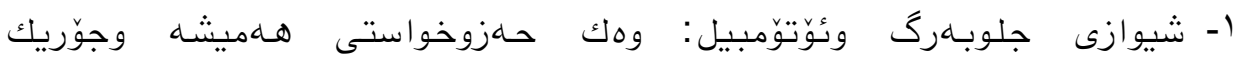

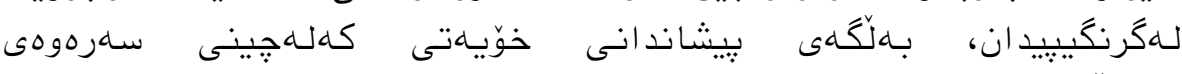

$$
\text { كوّمهالكَّهد ايهه. }
$$

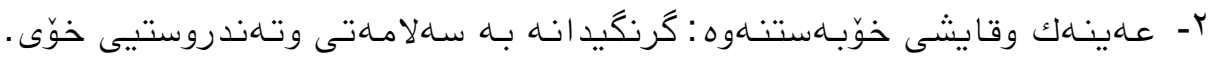

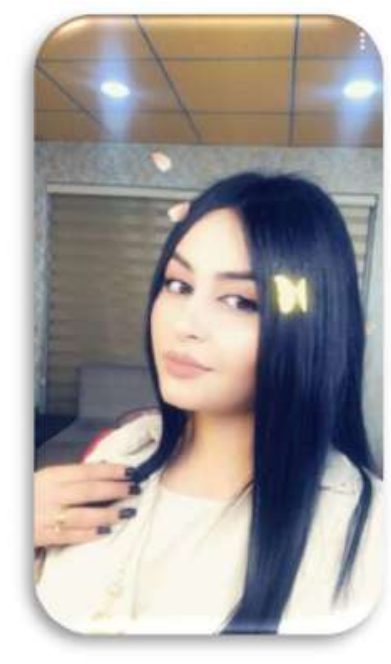

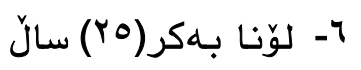

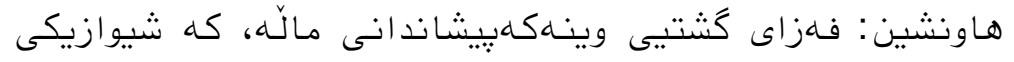

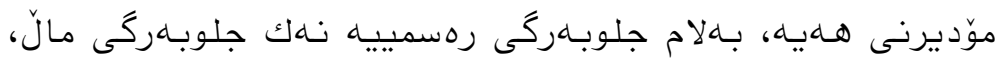

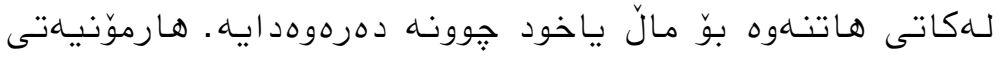

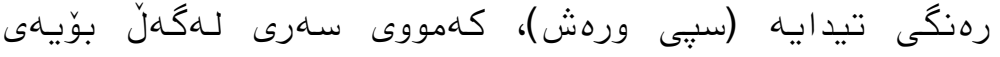

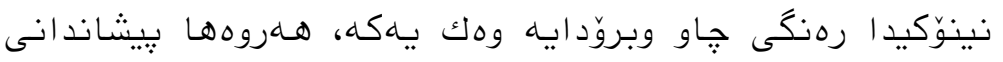

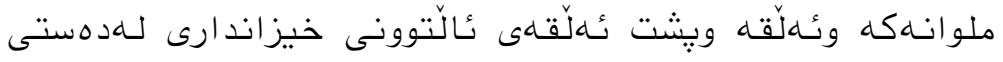

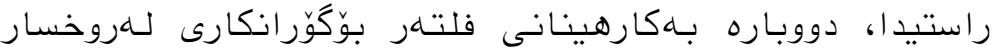

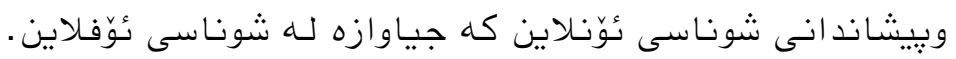

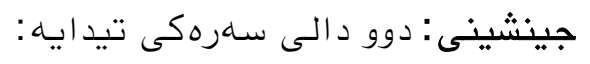

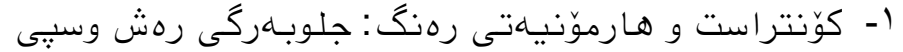

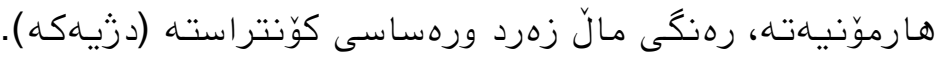

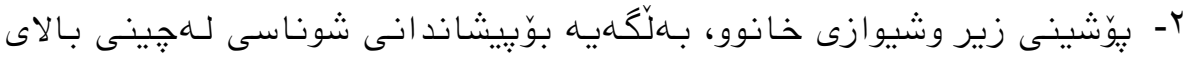

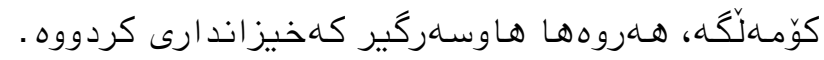



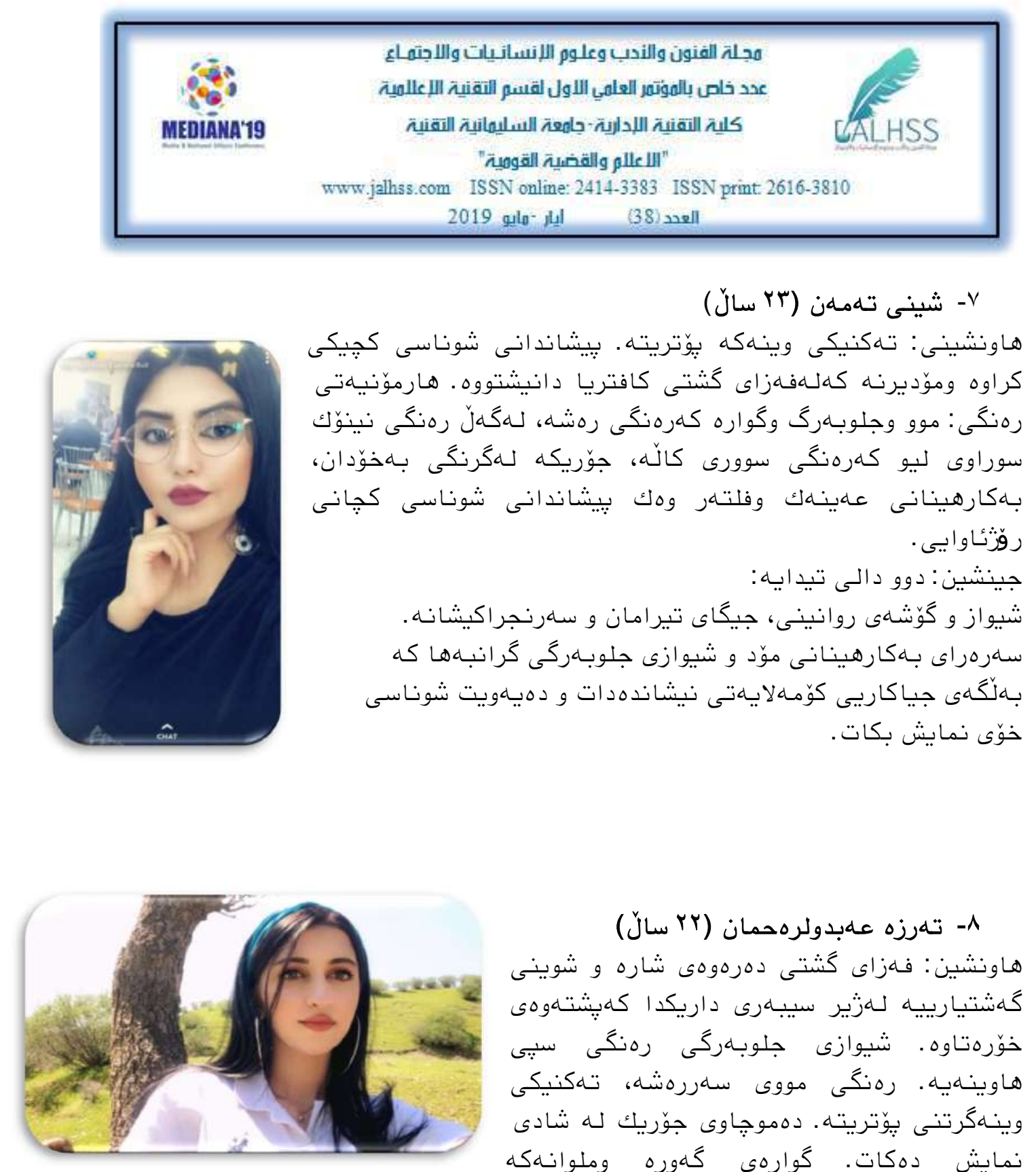

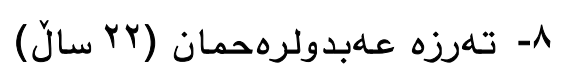

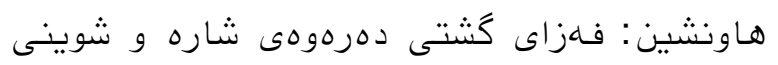

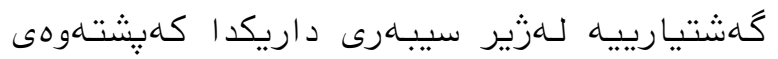

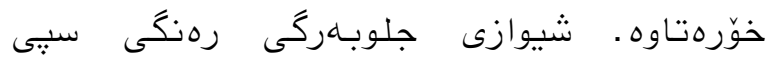

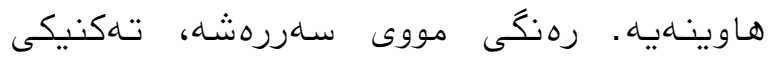

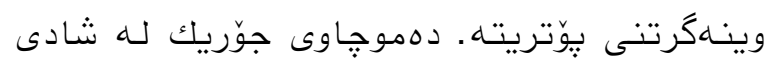

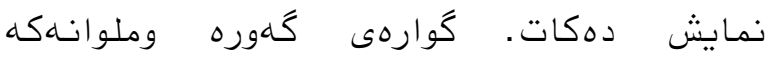

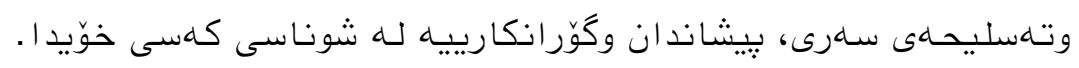

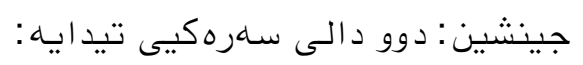

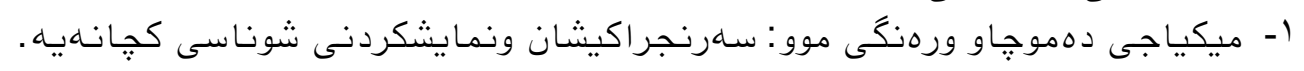

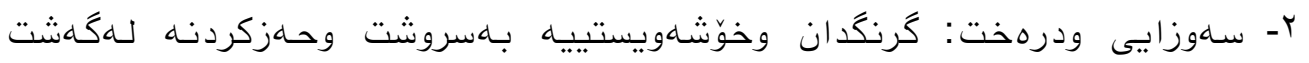
وسهيران. 

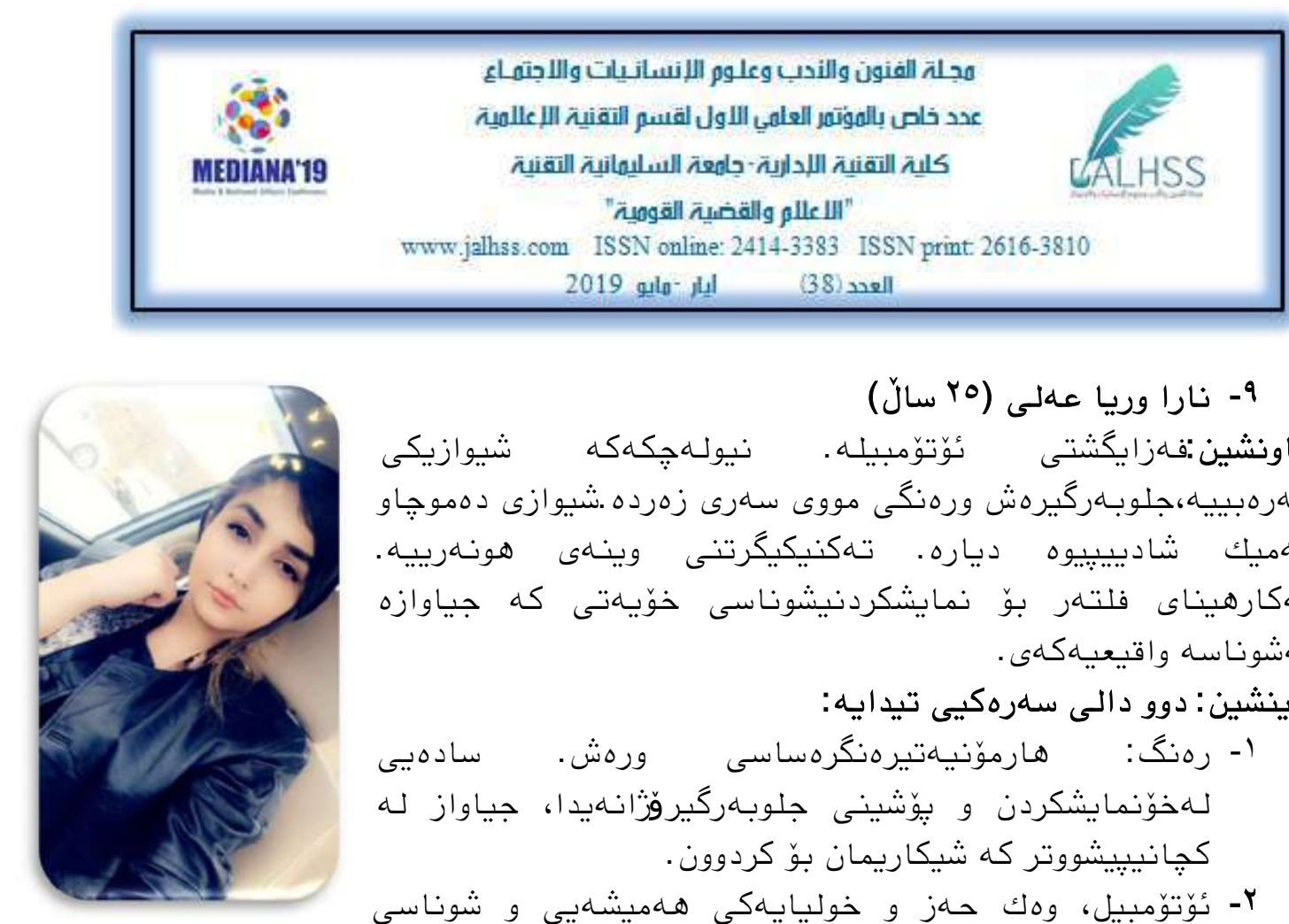

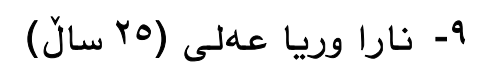

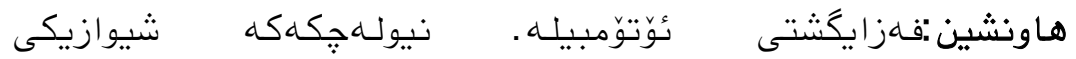

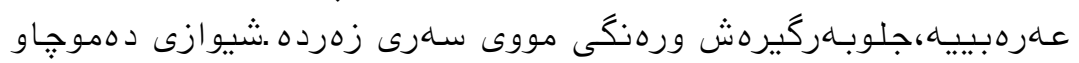

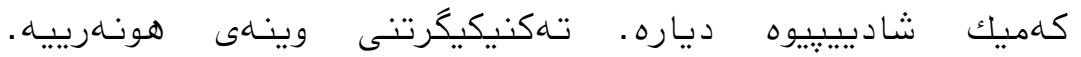

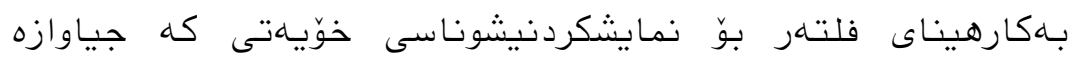

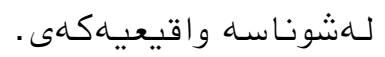
جينشين: دوو دالى سهرهكيى تيدايه:

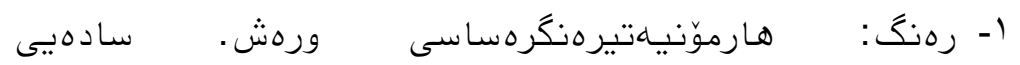

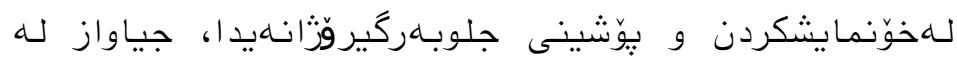

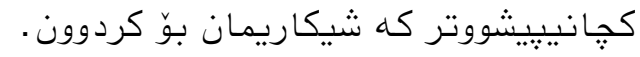

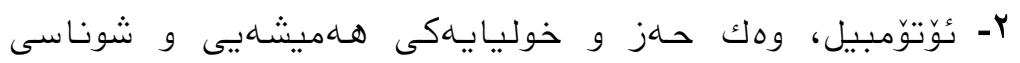

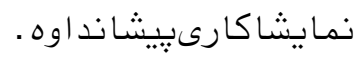

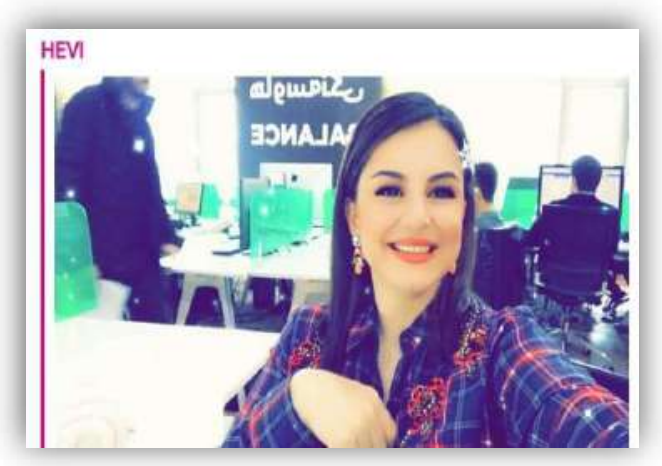

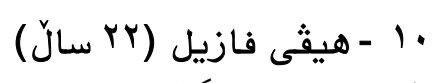

هاونشين: فهزاى كثتى شورئ شوينى رهسميى كاركردن،

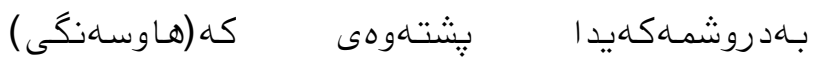

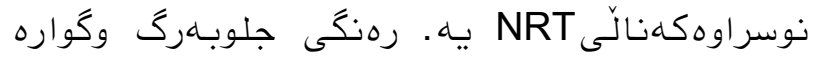

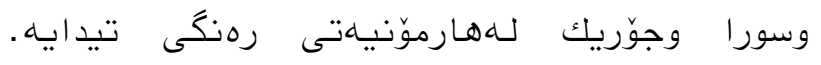

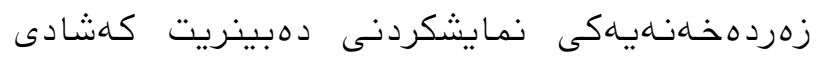

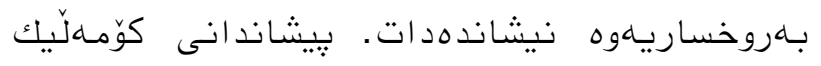

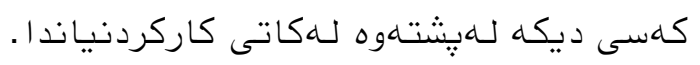

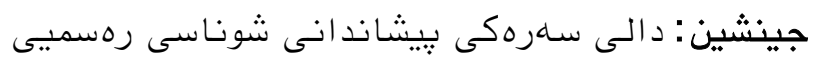

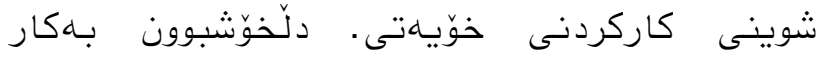

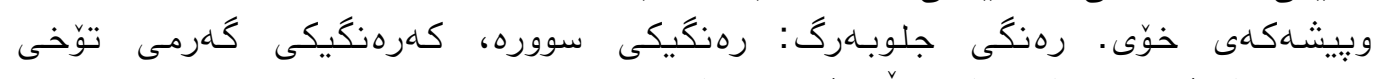

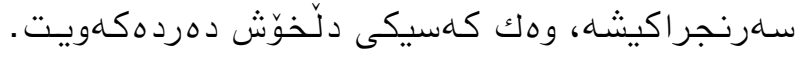



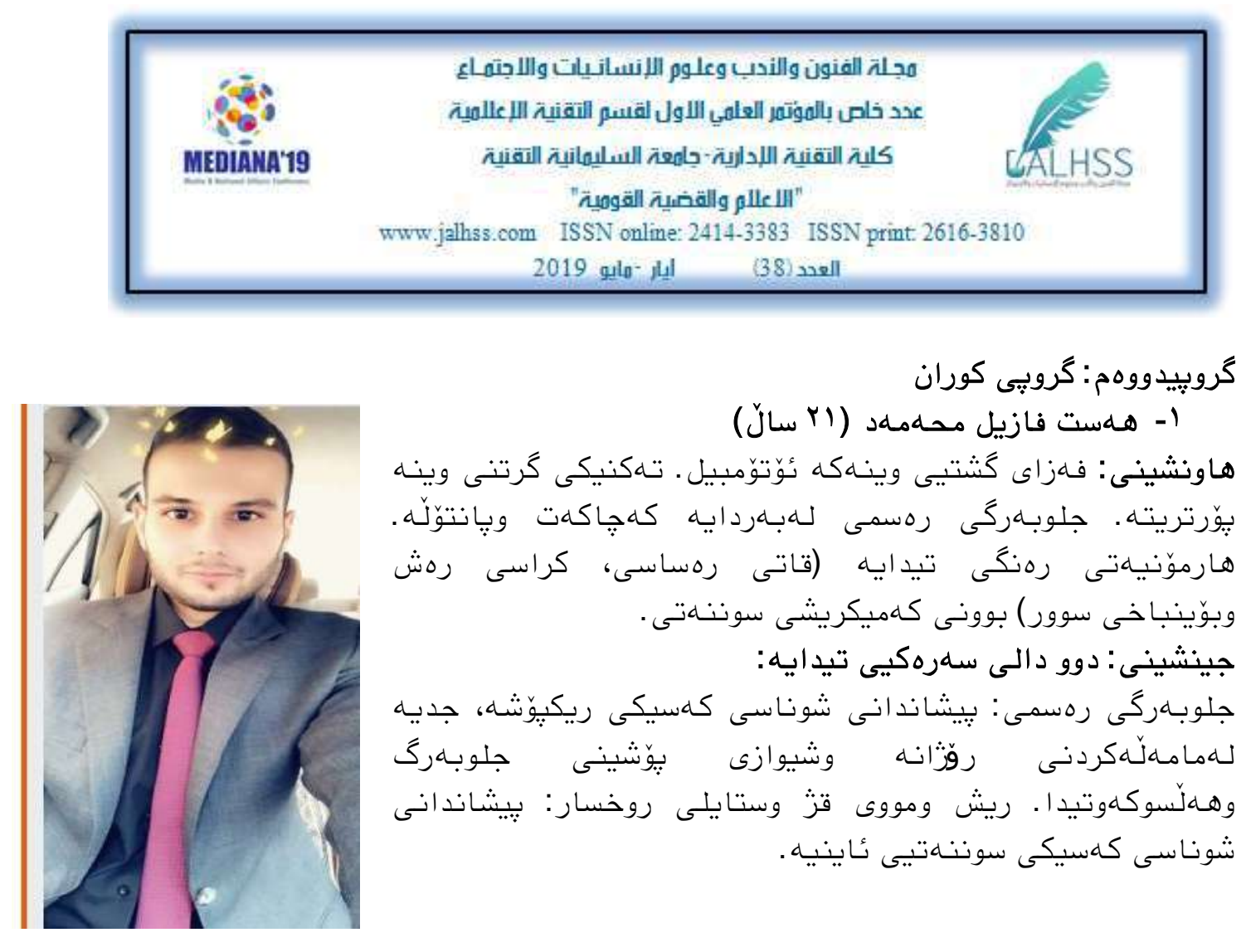

$$
\text { r- زير ئوميد عهلى (ابلى سالَ) }
$$

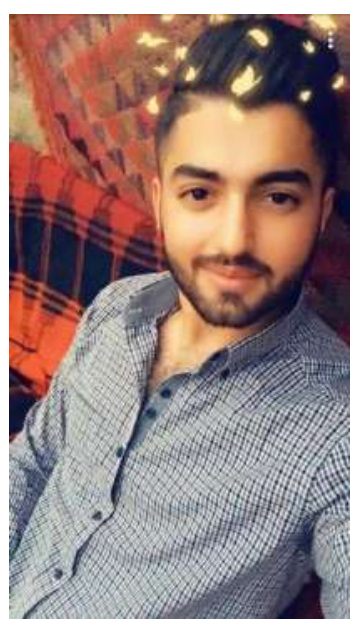

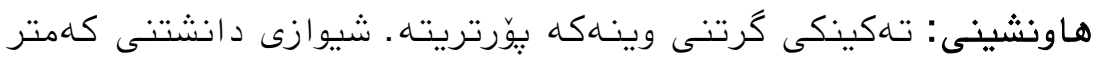

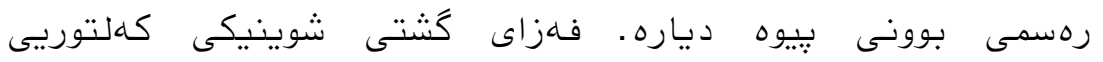

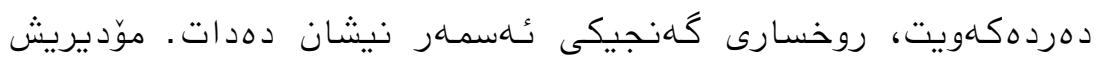

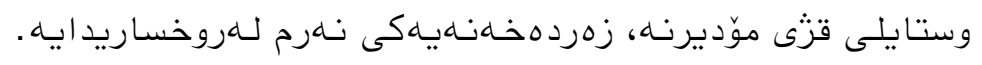

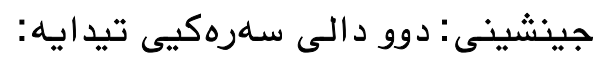

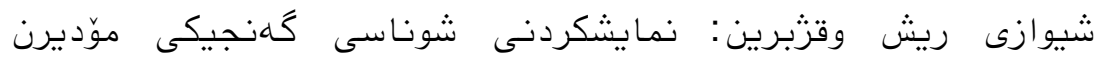

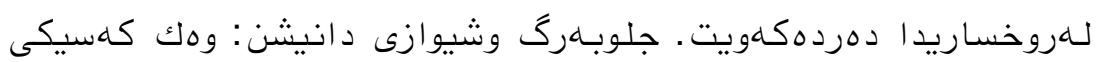

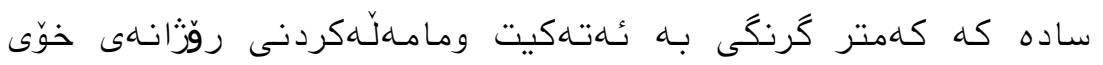
دهدات. 

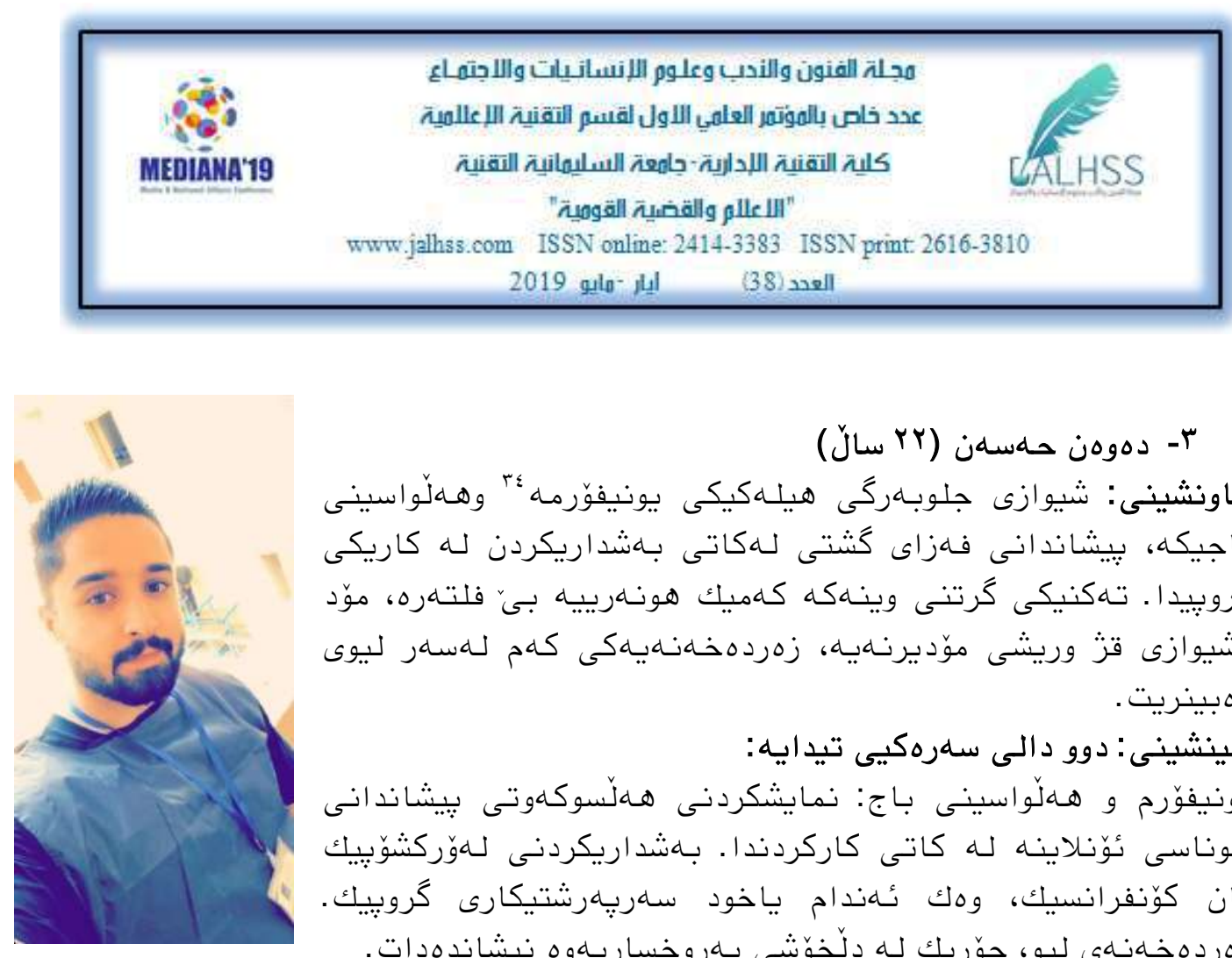

$$
\text { r }
$$

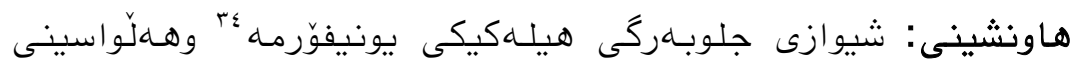

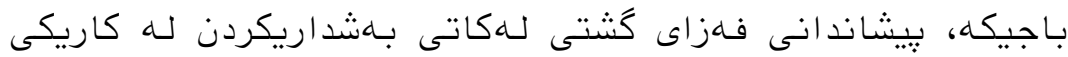

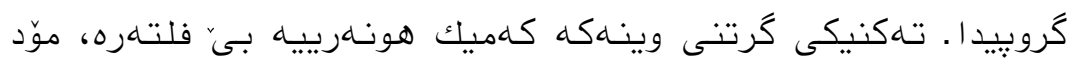

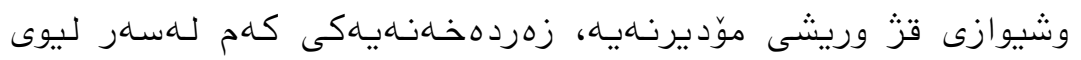

$$
\text { دهبينريت. }
$$

$$
\text { جينشينى: دوو دالى سهرهكيى تيدايه: }
$$

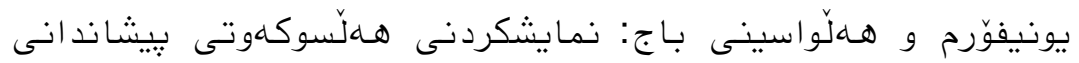

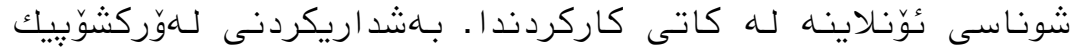

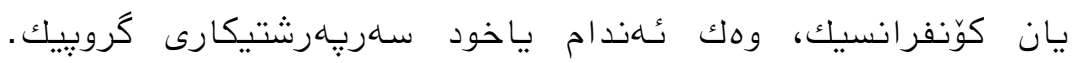

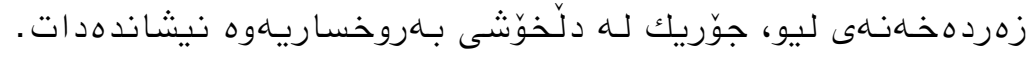

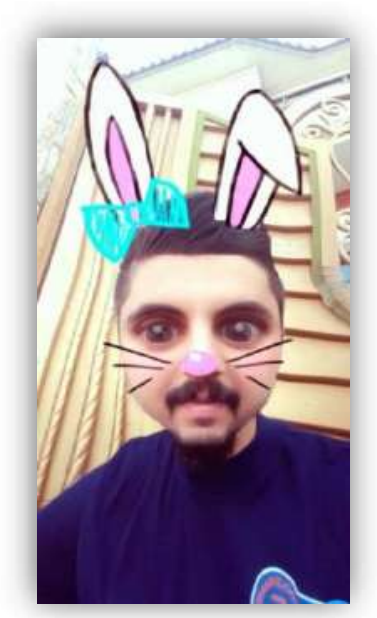

$$
\text { ع- هيمن شيخ حهسهن (r r سالّ) }
$$

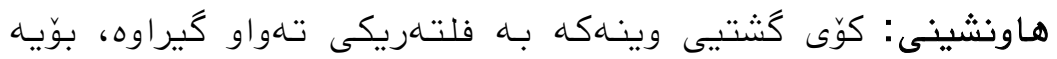

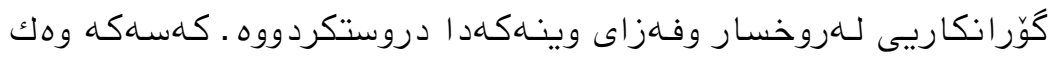

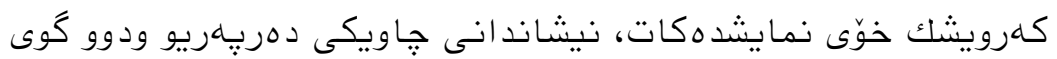

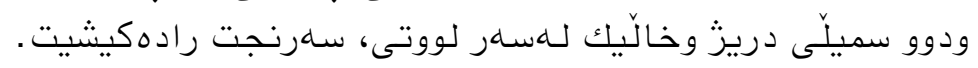

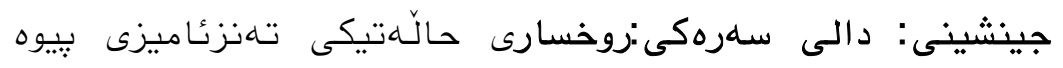

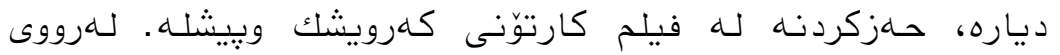

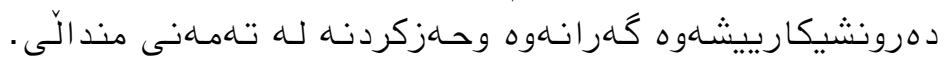

${ }^{34}$ Uniform 

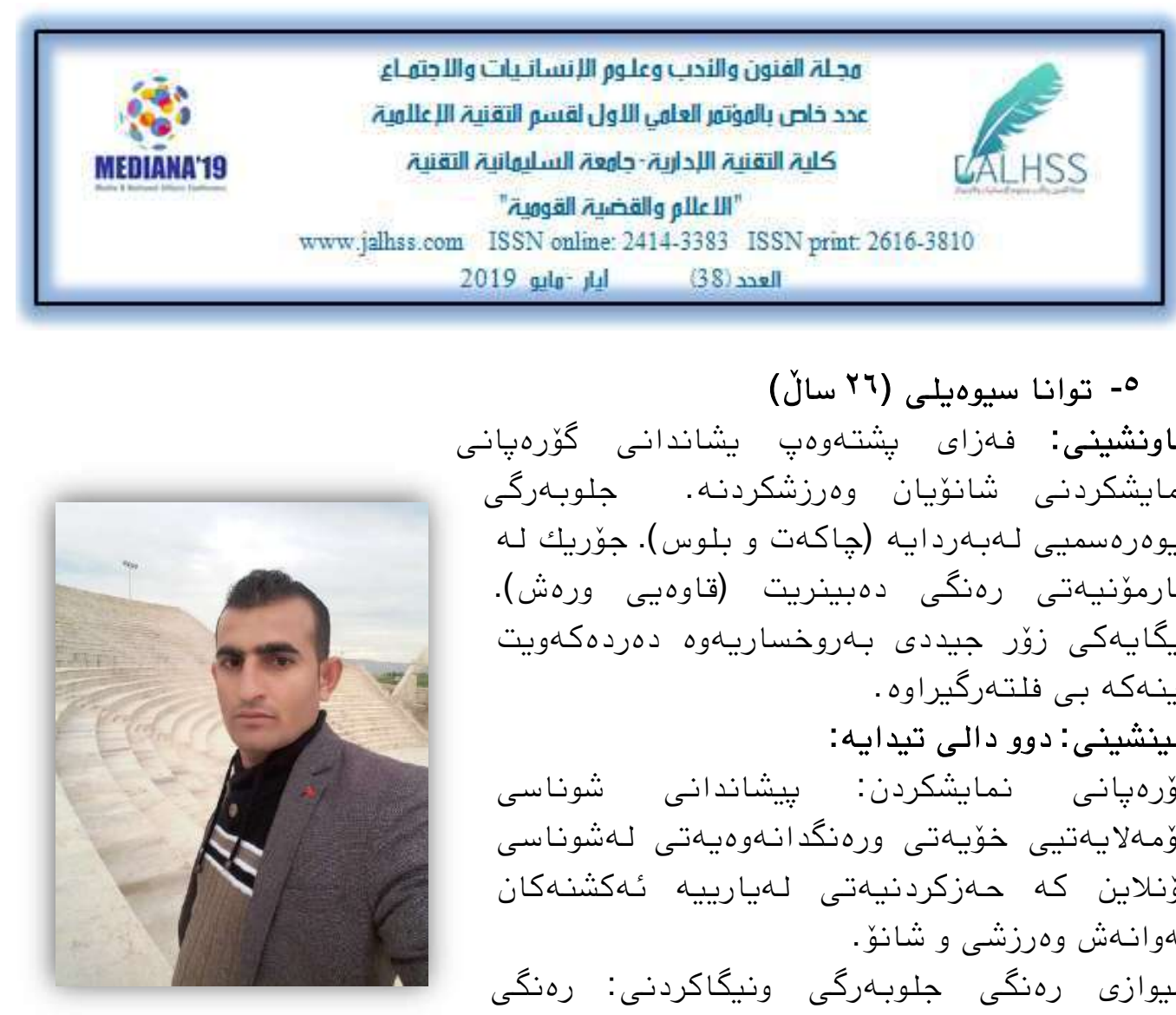

$$
\text { 0- توانا سيوهيلى (Tr سالّ) }
$$

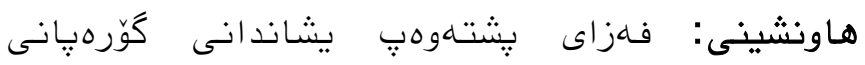

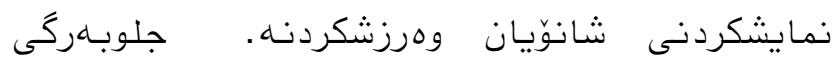

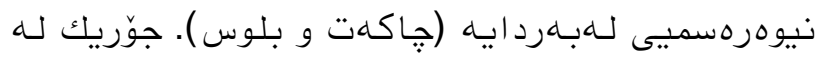

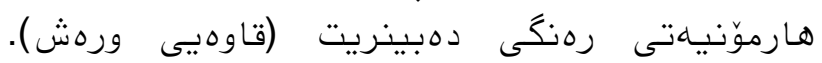

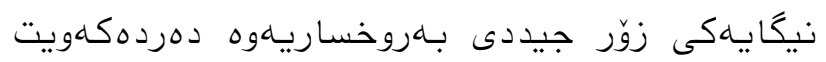
وينهكه بـى فلتهركيراوه. جينشينى: دوو دالى تينه تليدايه:

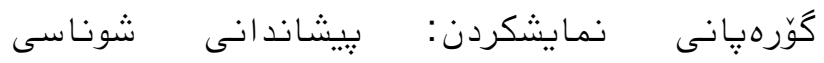

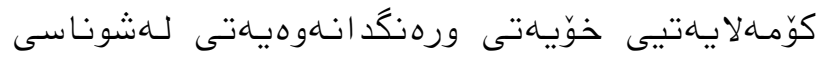

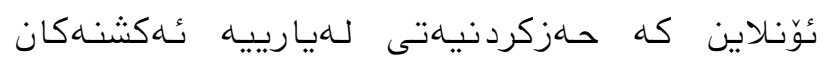

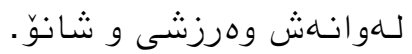

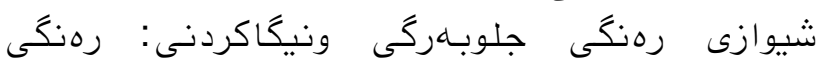

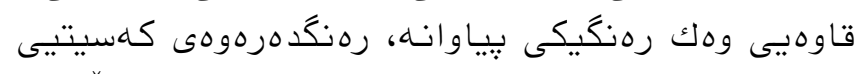

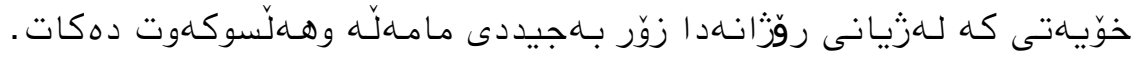

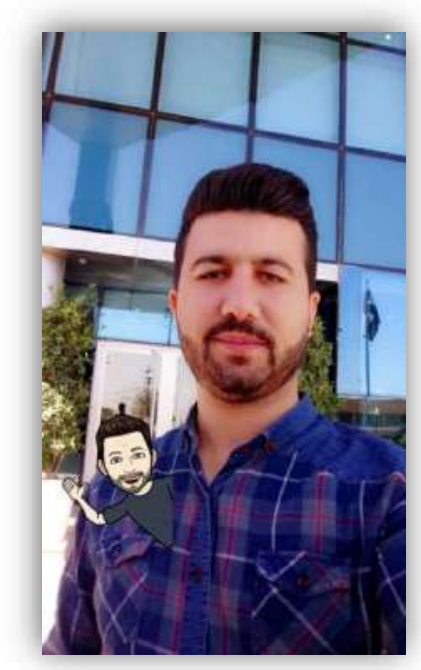

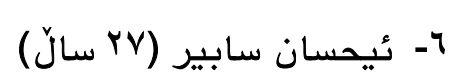

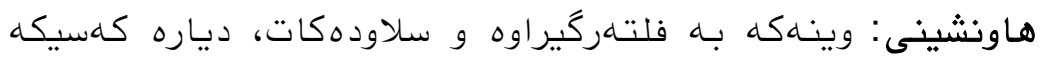

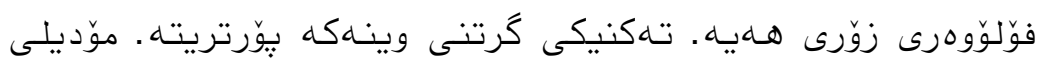

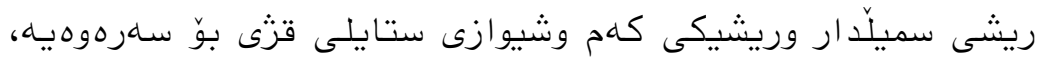

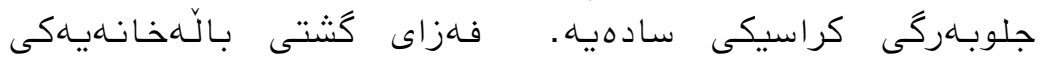

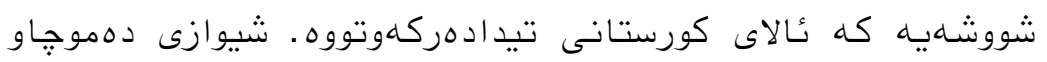

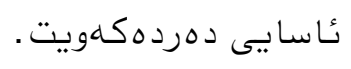

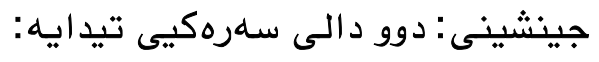

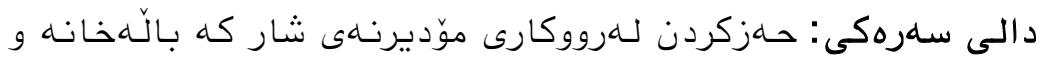

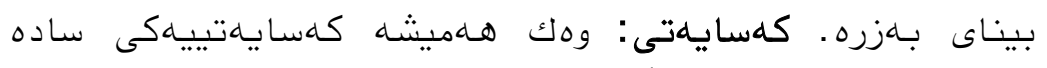

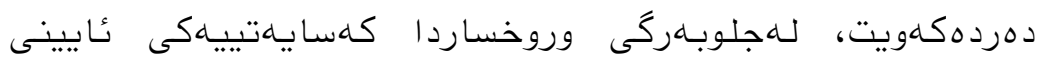

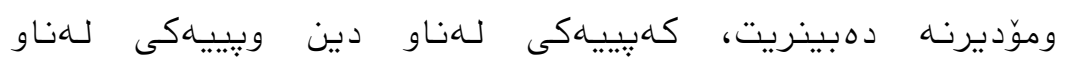

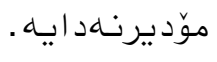



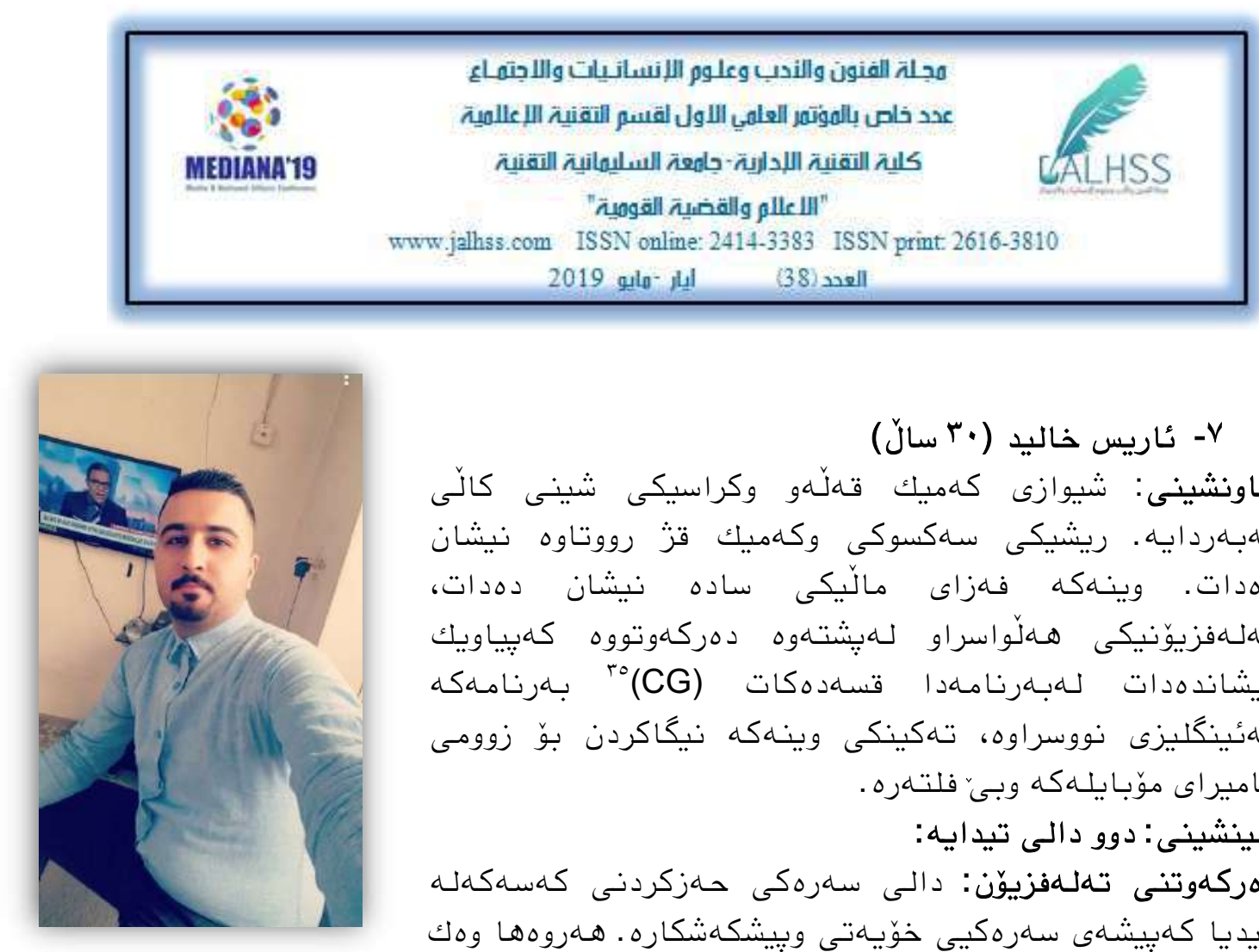

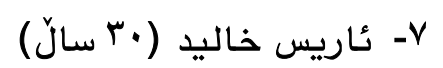

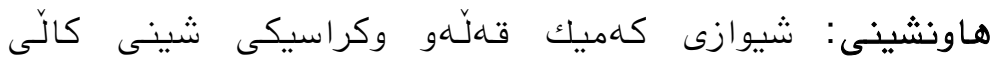

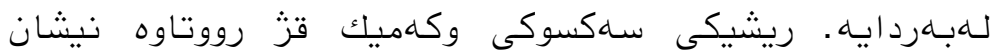

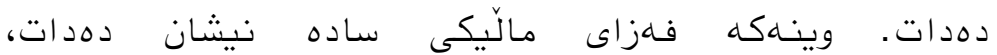

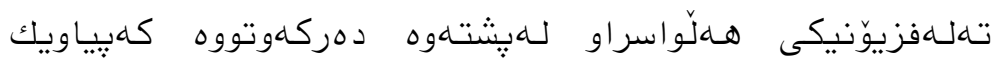

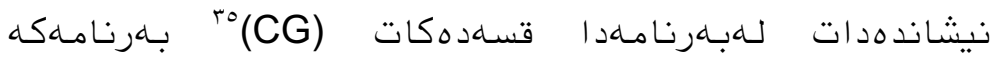

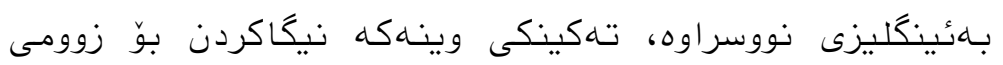

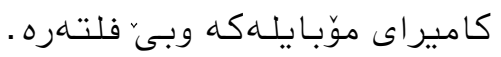
جينشينى :دوو دالى تيدايه:

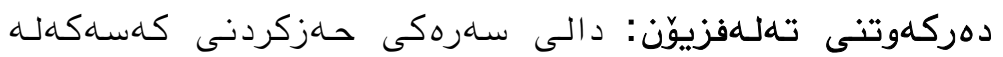

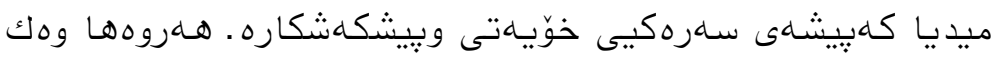

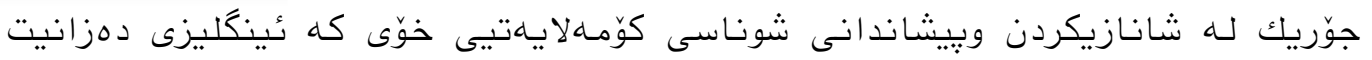

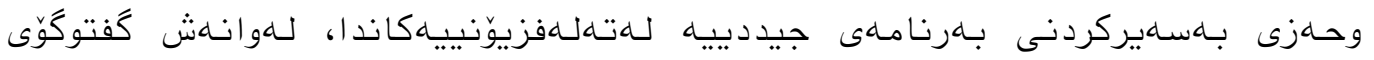

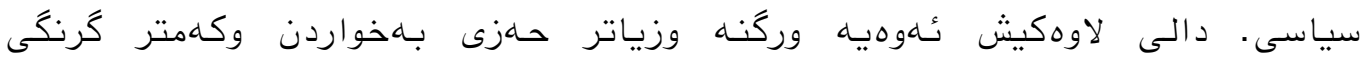

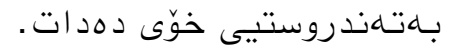

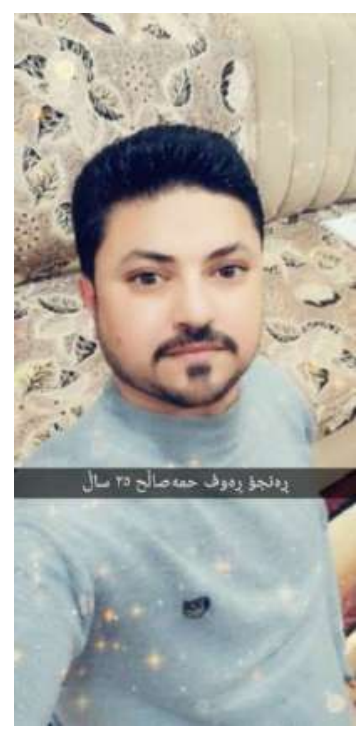

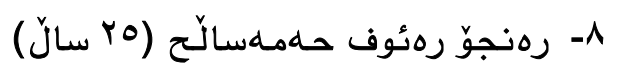

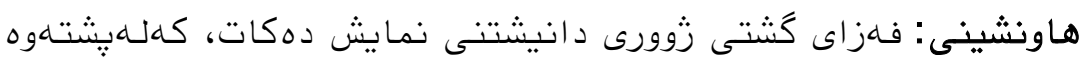

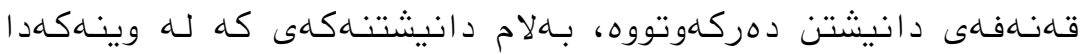

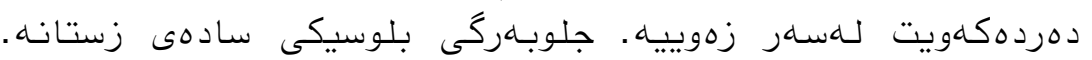

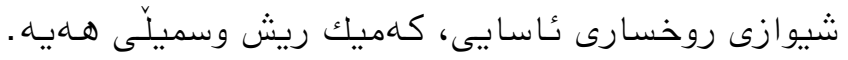

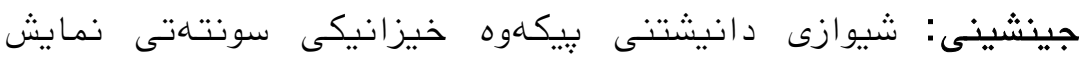

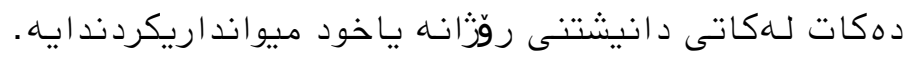



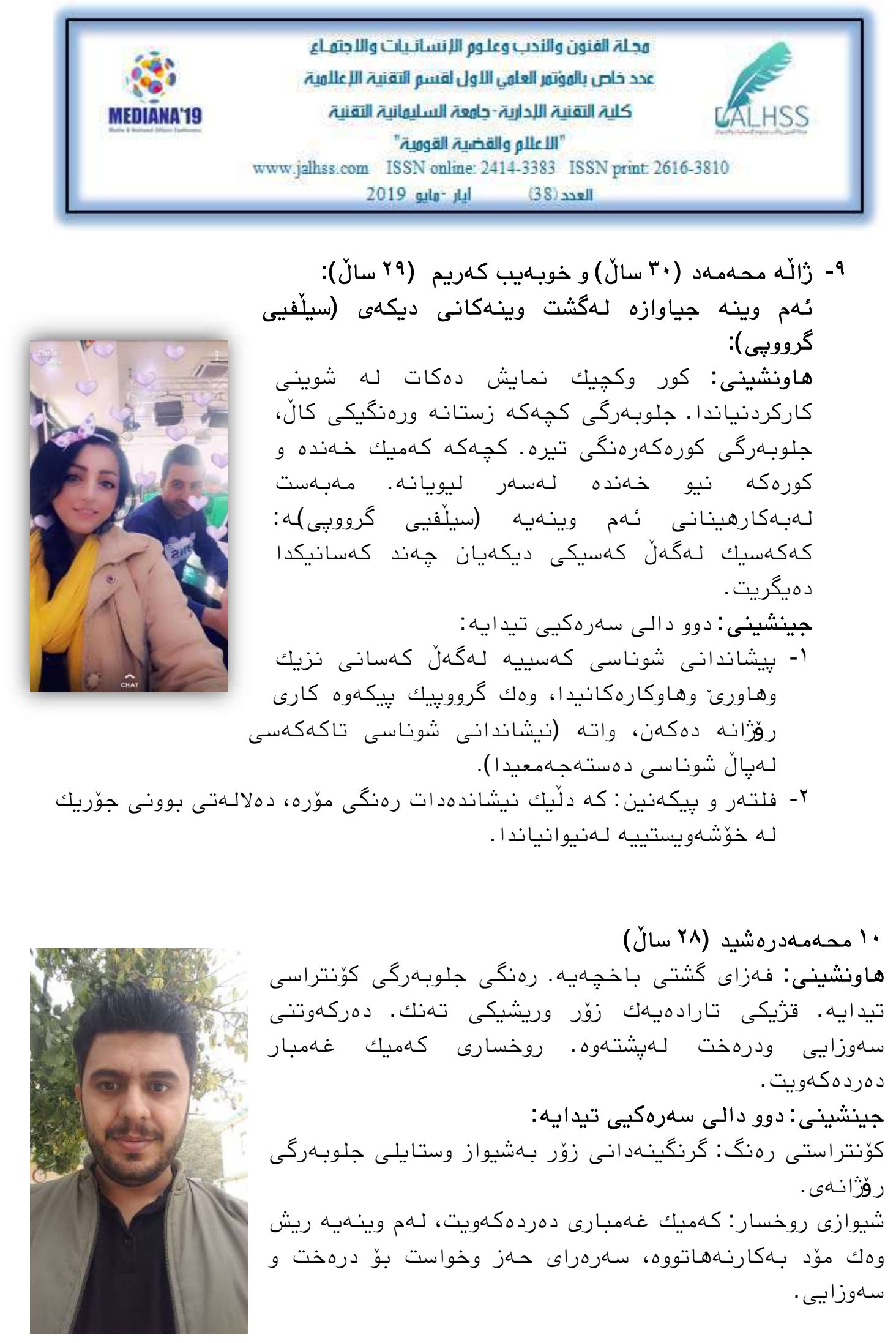


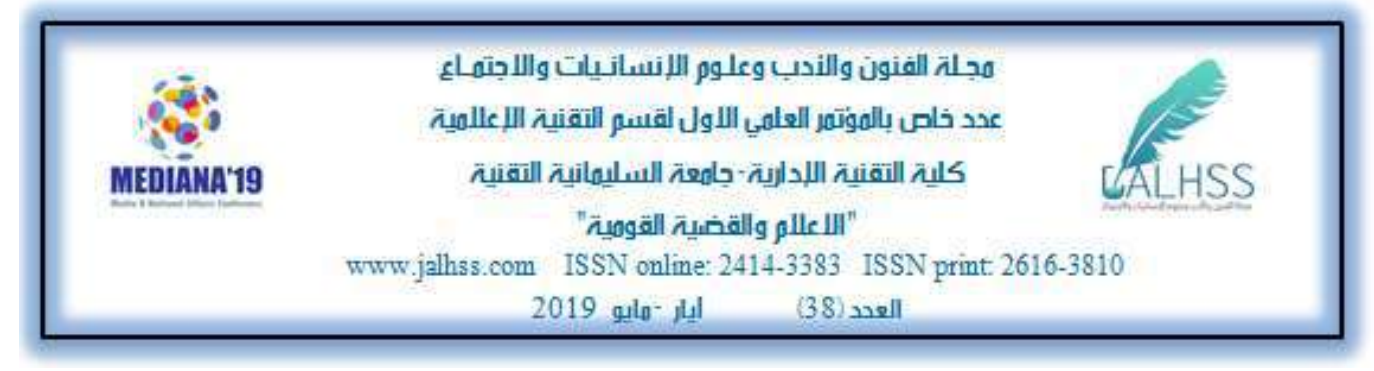

دهئهنجام

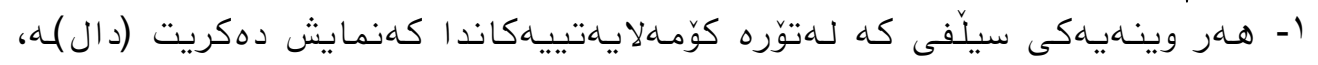

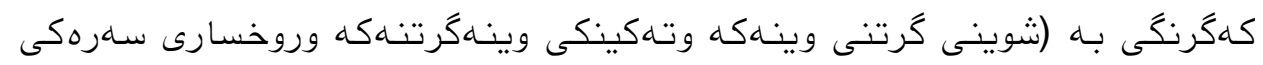

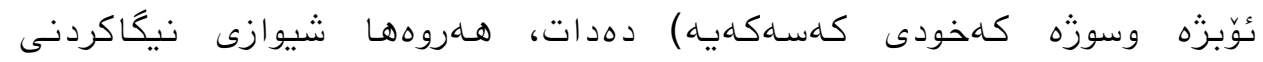

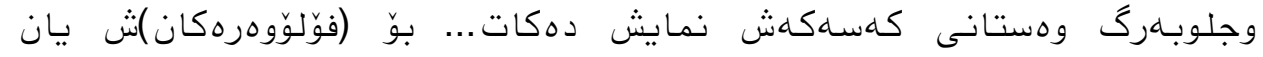

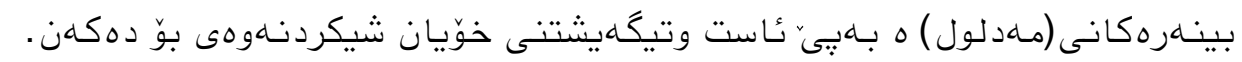

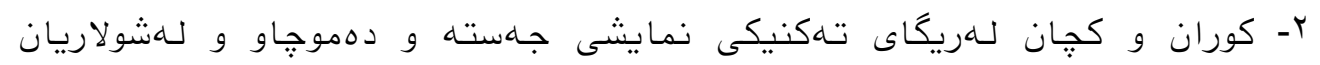

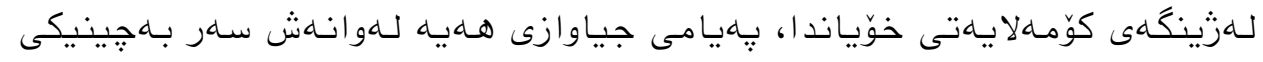

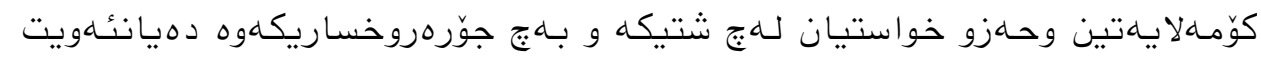

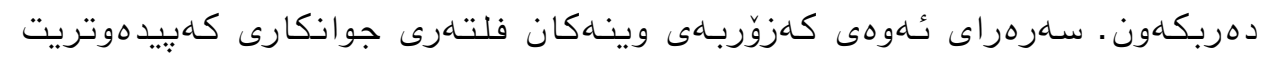

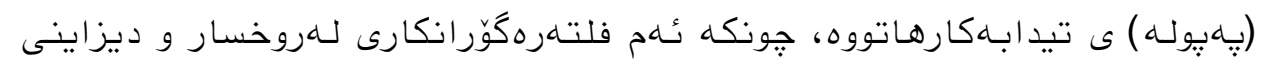

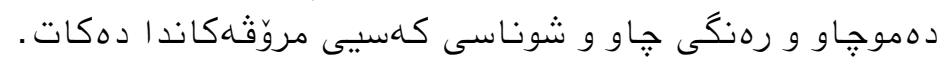

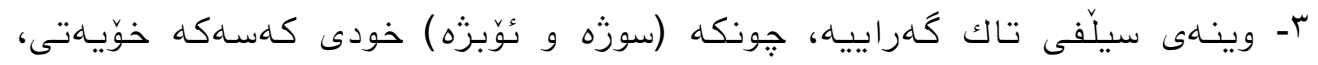

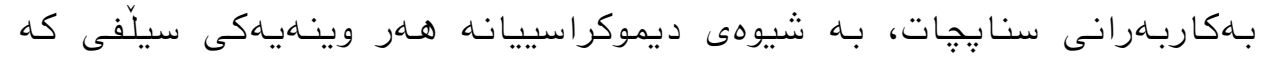

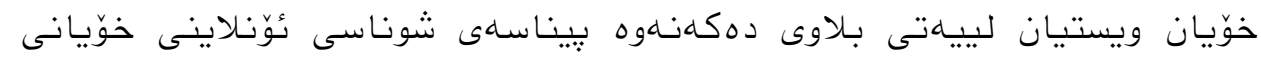

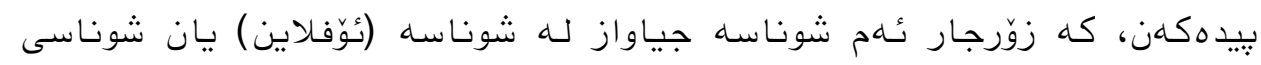
كوّمهالايهتيان.

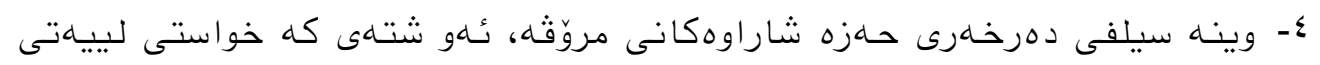

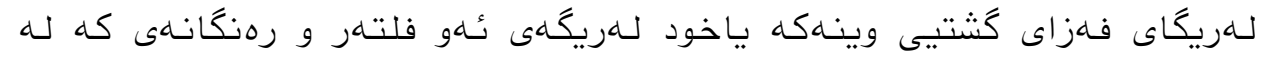

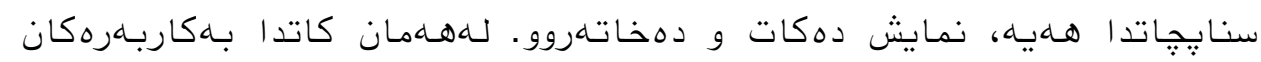

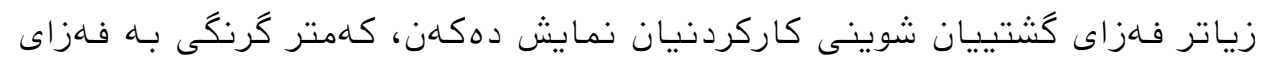

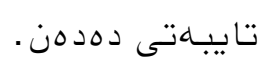

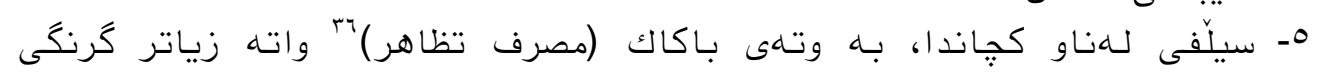

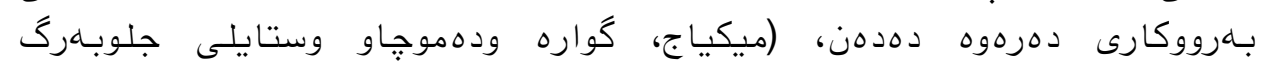

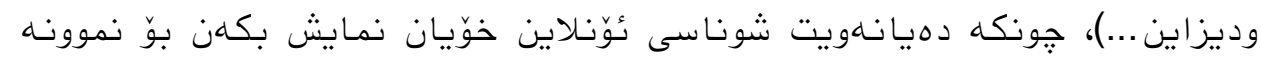

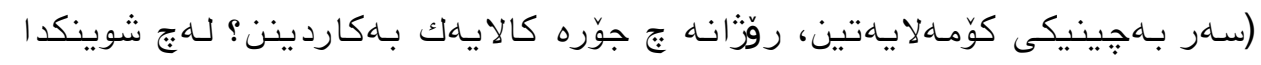

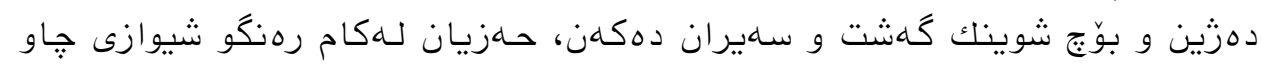

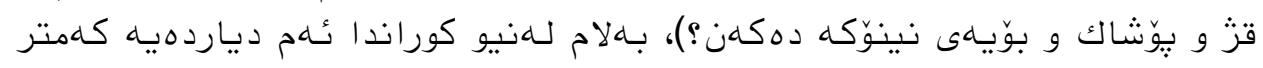

$$
\text { دهبينريت. }
$$

\footnotetext{
${ }^{36}$ Dementia consumption
} 
Sising
هجلم الفنون والندب وعلوم اللإنسانيات واللاجتهـاع

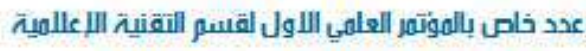

كلية التقنية اللدازية جاهعت السليهانية التقنيت

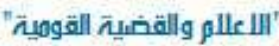

www.jalhss.com ISSN online: $2414-3383$ ISSN print $2616-3810$

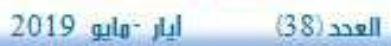

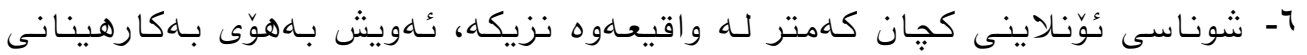

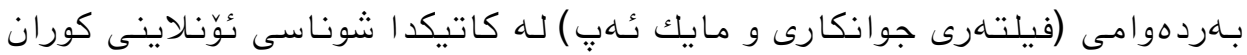

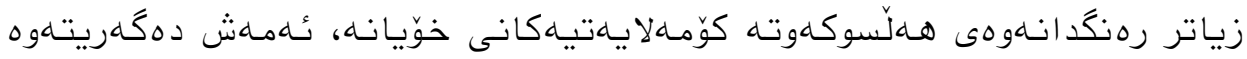

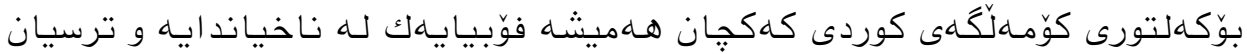

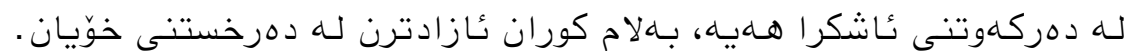

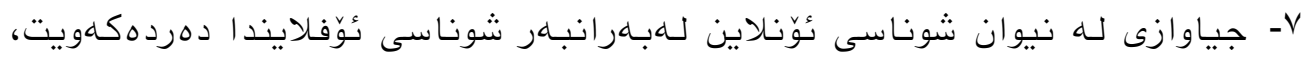

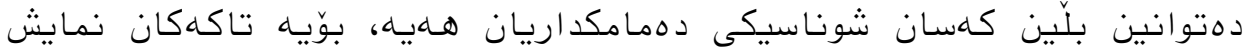

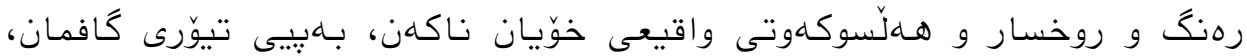

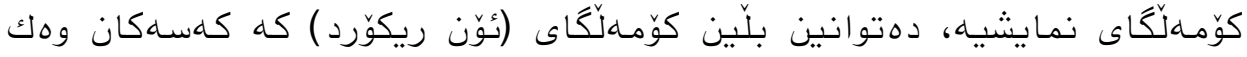

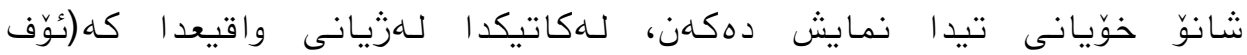

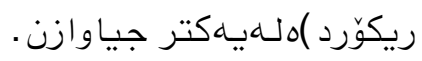

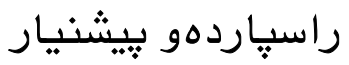

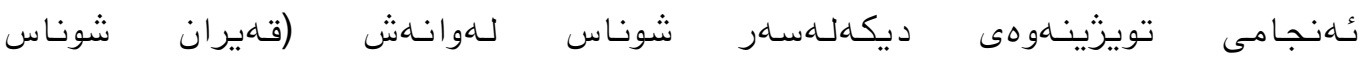

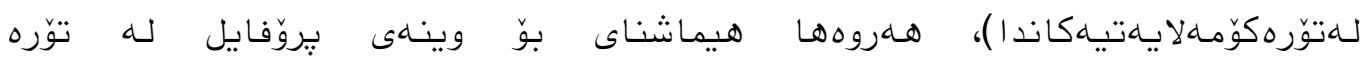

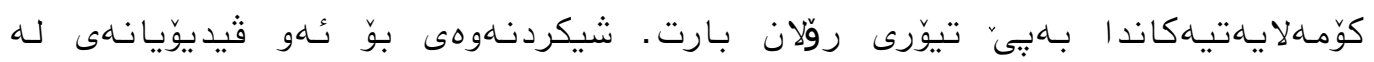

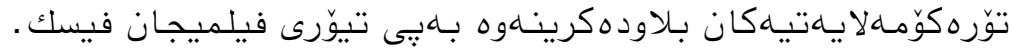

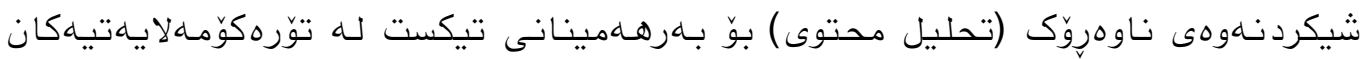

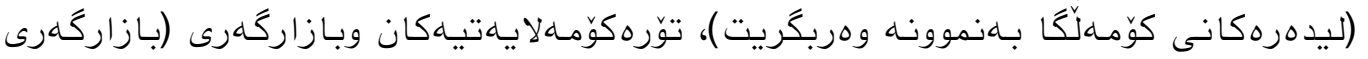

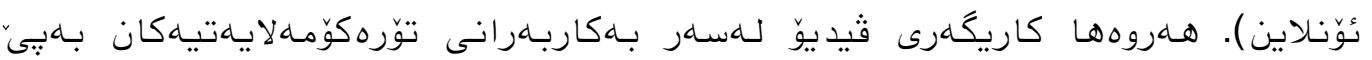

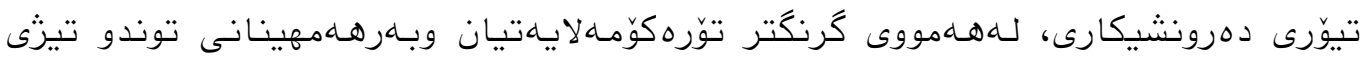
(تيروَّريزمى ميديايسى).

$$
\text { سلرجاوهان }
$$

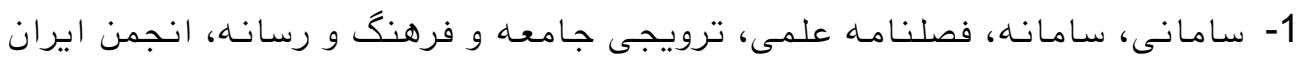

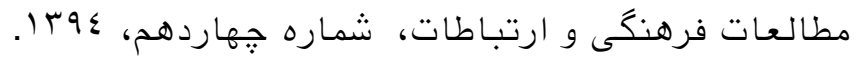

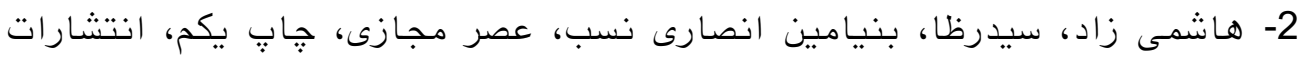

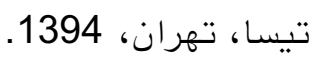

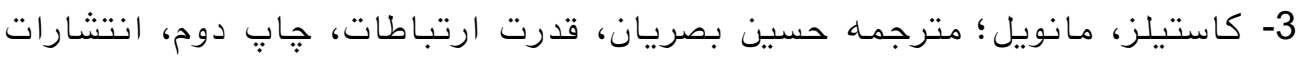

$$
\text { علمى فرهنگى، تهران، } 1397 .
$$

4- افراسياب، محمد سادق، مطالعات شبك، شنه ایى اجتماعى سبك زندكى جوانان، انتشارات سيما شرق، تهران: 


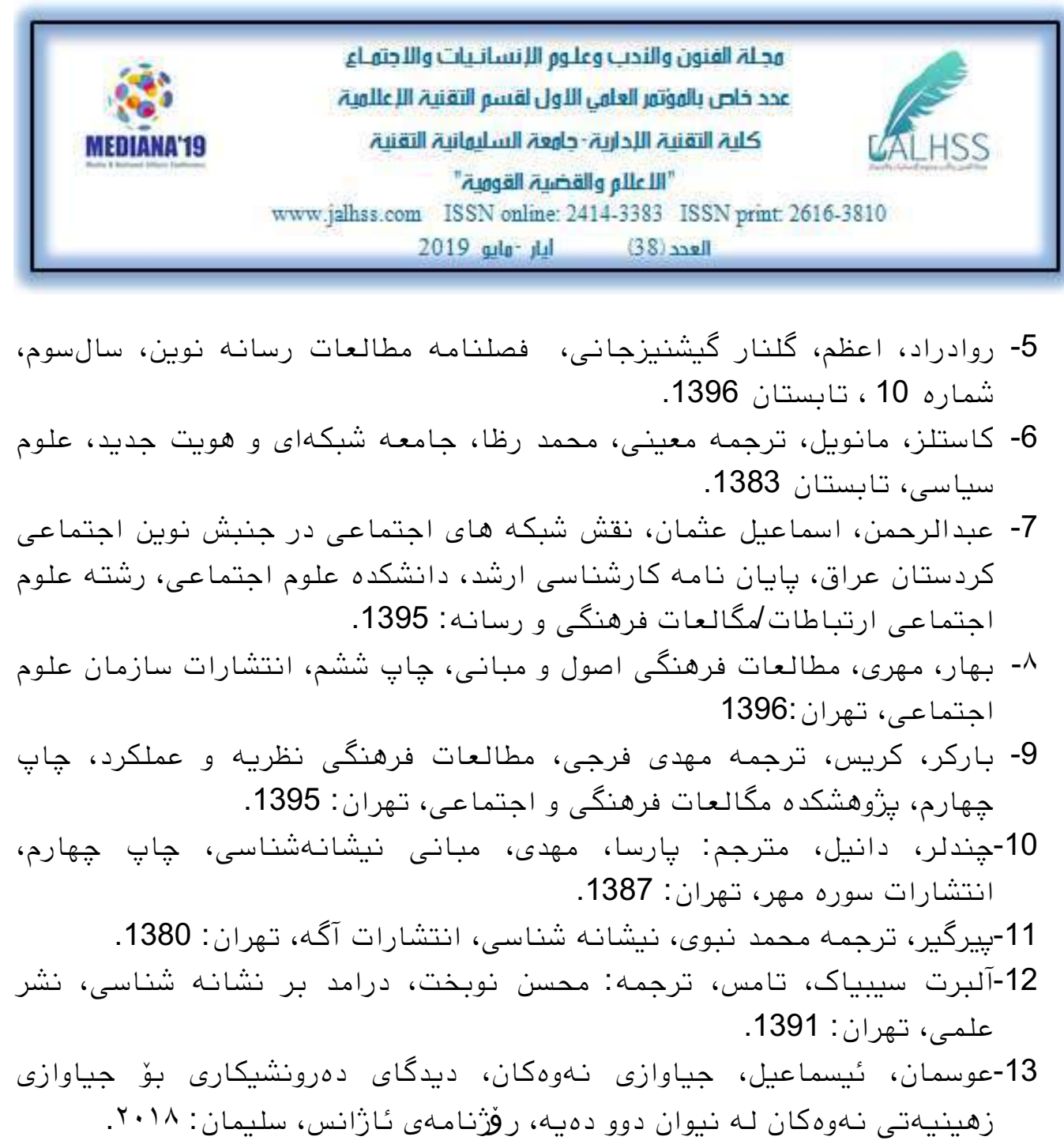

14- Van Dijk, jose, digital photography communication, Identity memoryin virtual communication:2008 